The Geological Society of America

Digital Map and Chart Series 14

2013

\title{
Geologic map and structure of the west-central part of the Grant Range, Nye County, Nevada
}

\author{
Phyllis A. Camilleri* \\ Department of Geosciences, Austin Peay State University, Clarksville, Tennessee 37043, USA
}

\begin{abstract}
The Grant Range exposes metamorphosed and unmetamorphosed Paleozoic strata and Tertiary granitic and andesitic dikes that collectively record a polyphase Mesozoic contractional and Cenozoic extensional deformational history. These structurally complex rocks are bounded on the west by a west-dipping normal fault system that cuts Quaternary alluvial deposits. In the west-central part of the range Cambrian and Ordovician strata are ductilely strained and regionally metamorphosed wherein metamorphic grade decreases stratigraphically upwards, generally commensurate with the degree of ductile strain. Upper Ordovician and younger strata are unmetamorphosed. Two Mesozoic phases of contractional deformation and protracted metamorphism are recorded within metamorphosed strata. The first phase produced mesoscopic eastvergent folds with spaced axial-planar cleavage. The second phase involved overprinting of the east-vergent folds by small-scale, west-vergent thrust faults and folds with sparse axial planar cleavage. Regional metamorphism began during east-vergent folding, but outlasted deformation producing static metamorphic textures. West-vergent deformation overprinted static metamorphic textures and effectively marked the end of metamorphism. On a regional scale, the aforementioned contractional structures are likely associated with larger scale folds and thrust faults exposed to the south and east of the map area. The east-vergent folds may have been parasitic to an east-vergent anticline that comprised the hanging wall of a large-scale top-to-the-east thrust fault, and west vergent structures may be back-folds and back thrusts. Regional correlations suggest that the Mesozoic structures and metamorphism predate $86 \mathrm{Ma}$.

The Mesozoic thrust faults and folds are cut by an arched, imbricate stack of predominantly brittle Cenozoic low-angle normal faults. The low-angle normal faults omit stratigraphic section, and each successively structurally higher fault is generally younger than the one below it. Sense of slip on most of the faults appears to be hanging wall (or top) - to-the-west. Some granitic and andesitic dikes cross-cut or are cut by low-angle normal faults, indicating that magmatism is at least in part synchronous with extension. The geometry of the low-angle normal faults suggest that these faults could be rotated, extinct fault segments formed as a result of arching of the upper reaches of the high- to moderate-angle west-dipping normal fault system responsible for the uplift of the Grant Range. The age of the low-angle normal fault system is probably late Oligocene to Pleistocene in age, but could be largely Miocene to Pleistocene.
\end{abstract}

$\overline{\text { *camillerip@ } a p s u . e d u}$

Camilleri, P.A., compiler, 2013, Geologic map and structure of the west-central part of the Grant Range, Nye County, Nevada: Geological Society of America Digital Map and Chart Series 14, 1 sheet, 25 p. text, doi:10.1130/2013.DMCH014. For permission to copy, contact editing @ geosociety.org. @2013 The Geological Society of America. All rights reserved. 


\section{INTRODUCTION}

The Grant Range forms part of the hinterland of the Jurassic to Cretaceous Sevier fold-and-thrust belt (Fig. 1), which is characterized by Mesozoic metamorphism and thrust faults and folds that are dismembered by Late Cretaceous to Quaternary extensional faults. Hinterland metamorphic rocks are predominantly exposed in a series of northeast-trending, spatially-separated metamorphic core complexes, which represent areas of extreme extension that resulted in exhumation of mid-crustal Mesozoic structural and metamorphic features (e.g., Crittenden, 1980; Coney, 1980; Armstrong, 1982; Coney and Harms, 1984; and many others; Fig. 1A). The midcrustal rocks in the core complexes are typically bordered and overprinted by Tertiary lowangle, normal-sense mylonite zones that are partly responsible for extensional exhumation. The Grant Range lies along the trend of the metamorphic complexes and is similar to the classic core complexes in that it contains thrust faulted and folded metamorphic rocks overprinted by low-angle normal faults, but it is unusual in terms of extensional structural style and the apparent lack of exhumation of deep, mid-crustal rocks with a superposed mylonitic shear zone (Fryxell, 1988). In the Grant Range, Mesozoic thrust faults and metamorphic features have been dismembered by several generations of relatively closely spaced, low- to high-angle normal faults (e.g., Fryxell, 1984, 1988, 1991; Lund et al., 1987, 1988; 1993; Camilleri 1988, 1992). The greatest amount of extension and exposure of the metamorphic rocks is present on the west flank of the southern part of the range, and this geologic map comprises the northernmost part of the extended metamorphic terrain (Fig. 1C). The map area is significant in that it (1) contains extraordinary exposures of an arched, imbricate array of low-angle normal faults that are geometrically similar to those predicted by the conceptual rolling-hinge type models of the evolution of large-scale normal faults (e.g., Wernicke and Axen, 1988; Buck, 1988; Hamilton, 1988), and (2) provides an exceptional record, and exposures of, Mesozoic tectonism and metamorphism. This paper documents and analyzes the aforementioned features and highlights structural and tectonic problems that remain to be addressed.

\section{PREVIOUS WORK AND MAP FRAMEWORK}

Hyde and Huttrer (1970) and Cebull (1970) presented the first detailed geologic mapping of the southern Grant Range that revealed metamorphosed and unmetamorphosed Paleozoic strata with a complex network of folds and younger-over-older and older-over-younger low-angle faults. They interpreted the low-angle faults to be exclusively Mesozoic thrust faults formed during development of the Sevier thrust belt. Their mapping was then compiled with adjacent work into a regional 1: 250,000 geologic map by Kleinhampl and Ziony (1985). Subsequent geologic mapping in the Grant Range by Lund et al. (1987, 1988), Fryxell (1984, 1988), and Bartley and Gleason (1990) revealed that most of the younger-over-older low-angle faults are Cenozoic normal faults that overprint earlier Mesozoic thrust faults and folds. Part of the area mapped by Lund et al. $(1987,1988)$ was subsequently mapped in detail at a scale of 1:12,000 by Camilleri (1988) with a focus on delineating the history and geometry of micro- to mapscale structure and fabric of Cambrian and Ordovician strata that form the metamorphic core of the northern part of the range. A simplified small-scale version of Camilleri's (1988) map and interpretation of the geometry and kinematics of the low-angle normal faults was presented in Camilleri (1992).

This paper and map presents the 1:12,000 scale Paleozoic bedrock map and detailed structural data of Camilleri (1988) combined with new mapping of Quaternary units and faults that is based primarily on 1:24,000 scale air photos and partly on field work (Fig. 2). Camilleri's (1988) bedrock map (and the map herein) includes some mapping of Silurian and younger rocks on the eastern and western margins of the map area by Lund et al. (1987, 1988 and unpublished data). The mapping of Silurian and younger rocks compiled and modified from Lund et al. (1987, 1988) is from 1:50,000 scale maps and hence shows less data (e.g., attitudes and units etc.) than the Cambrian and Ordovician rocks, which were mapped at a scale of 1:12,000 (the location of data compiled from Lund et al. is shown in Fig. 2).

\section{GEOLOGIC SETTING OF THE SOUTHERN GRANT RANGE AND VICINITY}

\section{Regional Setting}

The southern Grant Range, and its southern extension the Quinn Canyon Range, are bounded on the west by a westdipping normal fault system (Fig. 1B). These ranges primarily expose metamorphosed to unmetamorphosed Paleozoic carbonate and clastic strata, Mesozoic and Cenozoic intrusives and Tertiary volcanic and volcaniclastic rocks. Paleozoic strata in these ranges are replete with low-to-high-angle normal faults that cut small-scale contractional structures and remnants of major thrust faults (e.g., Lund et al. 1987, 1988, 1993; Fryxell 1984, 1988, 1991; Camilleri 1988, 1992; Bartley and Gleason 1990; Taylor et al., 2000). However, one regional Tertiary low-angle normal fault, the Troy Peak fault, appears to structurally divide this area into two major plates (Fryxell, 1991; Fig. 1C). The hanging wall of the Troy Peak fault contains remnants of two top-to-the-east thrust faults, the Sawmill and Rimrock thrusts, with the Rimrock thrust being cut by the Troy Peak fault (Bartley and Gleason 1990; Fryxell, 1991; Fig. 1C). The Sawmill and Rimrock thrusts place lower Paleozoic strata on upper Paleozoic strata. The footwall of the Troy Peak fault contains the metamorphic core of the Grant Range and one major thrust, the Schofield thrust, which is cut by the Troy Peak fault (Fryxell, 1991). The Schofield thrust juxtaposes Cambrian over Ordovician strata and contains the map-scale, overturned Timber Mountain anticline in its hanging wall. The anticline is developed in regionally metamorphosed and unmetamorphosed Cambrian rocks adjacent to the Troy Pluton (Fig. 1C; Cebull, 1970; Fryxell, 1984, 1988, 1991). The Timber 


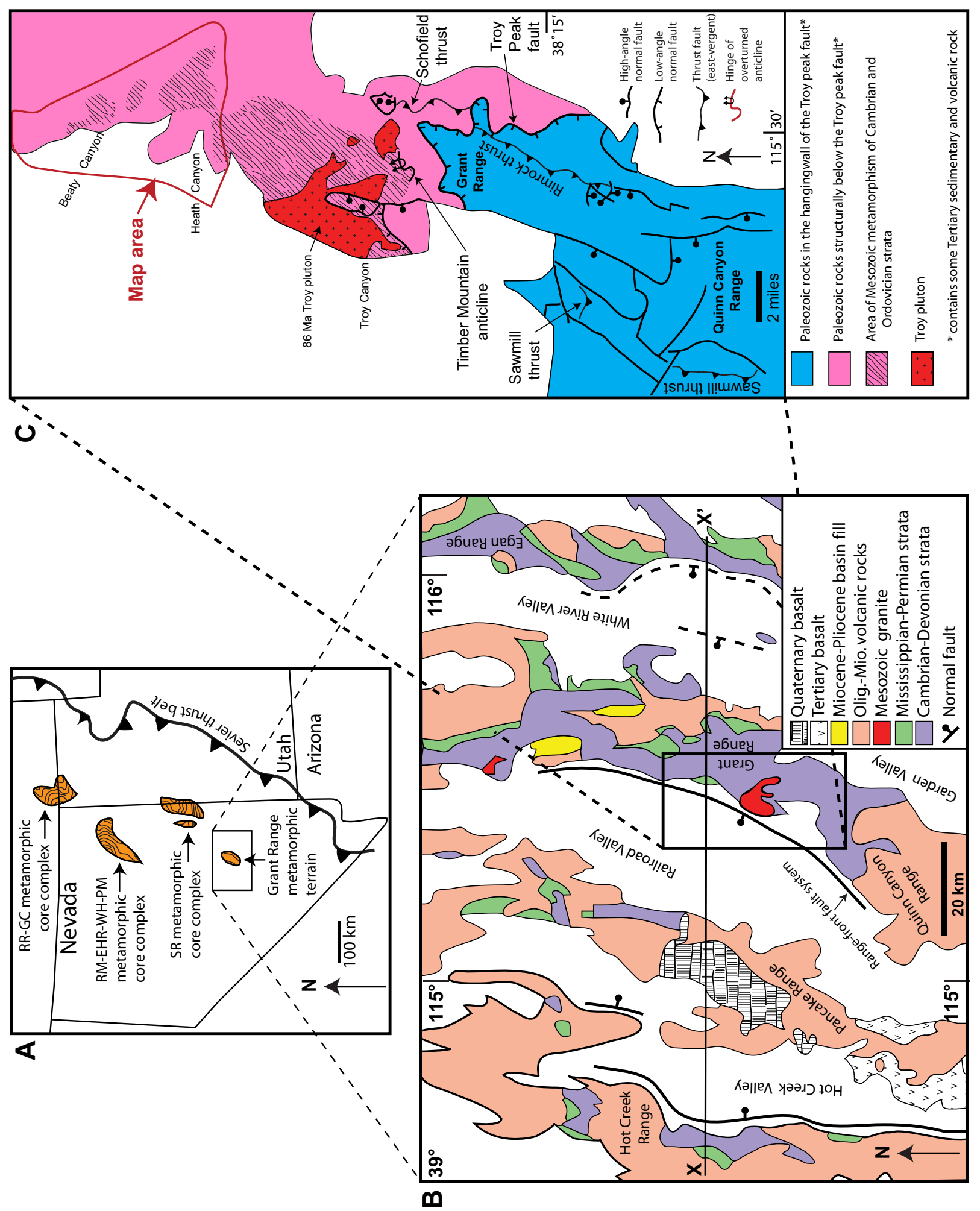

式

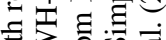

皮远的

岸守包

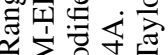

$\pm \cong$

过运施

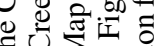

$\Xi \amalg \Sigma \Xi$

눙

ठํ.

政

을

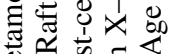

॥ ङ

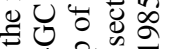

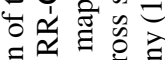

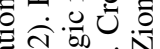

응 웅

일

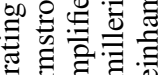

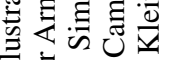

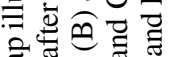

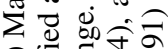

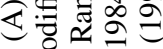

$\dot{\phi} \Sigma \bar{\nu}=$

政

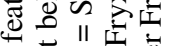

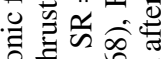

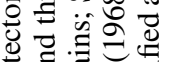

증 흥 苛

50

.

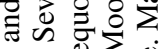

$\therefore$

政空

驻

즌

证

응

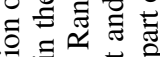

당 흥 흥

웡

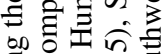

F 0 范

o

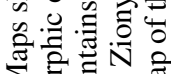

훙효

휸 $\sum^{2}$

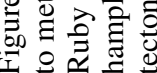




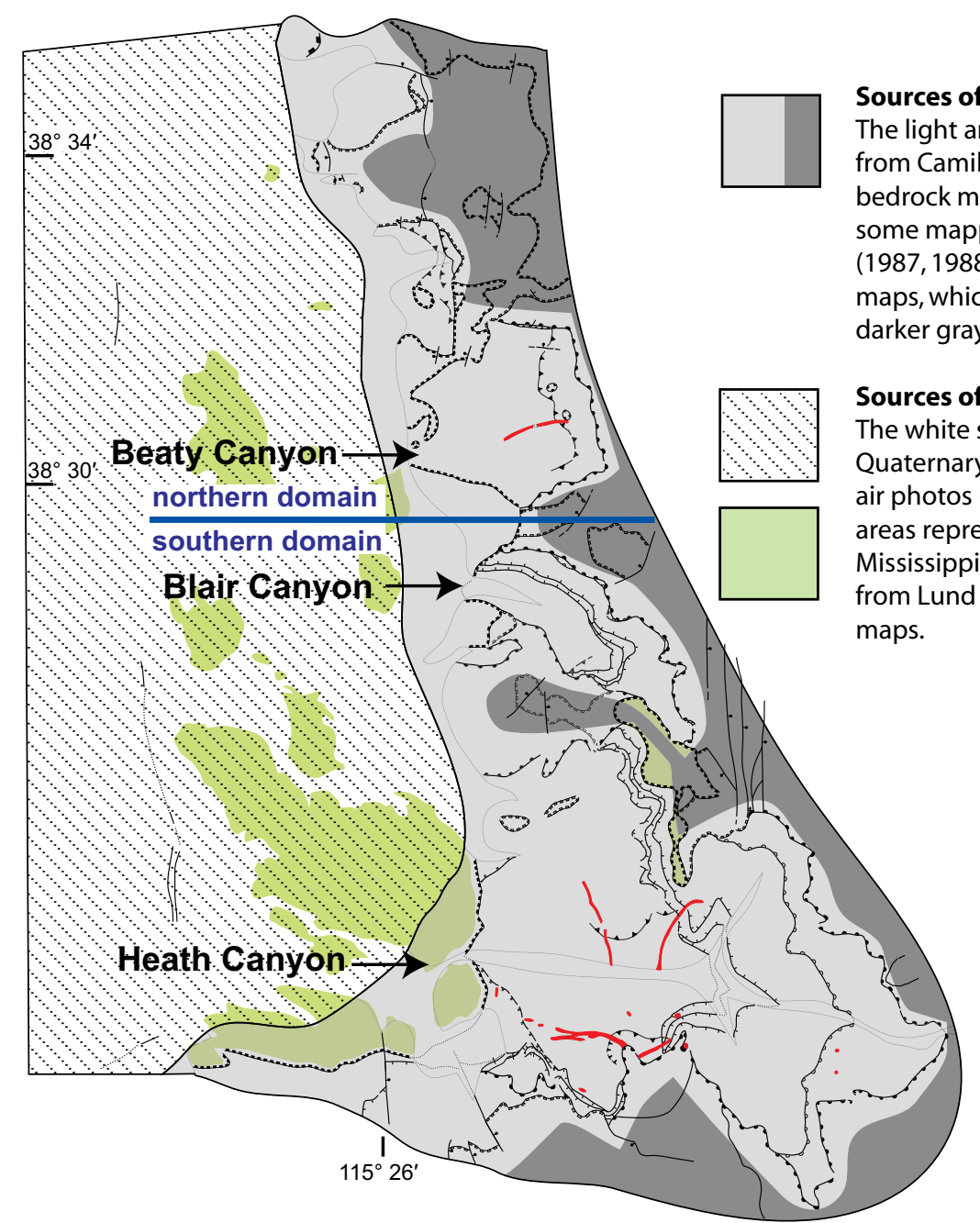

Figure 2. Map showing the sources of geologic mapping. The locations of major faults (bold black lines), Tertiary intrusives (red), and the boundary between the northern and southern domains (blue line) are also shown. See Figure 1C for location of the map area. Unit symbols are shown on the map legend.

Mountain anticline and metamorphism predate emplacement of the $86 \mathrm{Ma}$ Troy pluton indicating a Late Cretaceous or older age of deformation and metamorphism (Fryxell, 1984, 1988, 1991; Taylor et al., 2000).

\section{Paleozoic and Quaternary Rock Units and General Structural Architecture of the Map Area}

The rocks exposed in the map area include limestone, dolostone and minor sandstone and shale of Cambrian to Mississippian age on the east, and poorly consolidated Quaternary alluvial and pluvial deposits on the west. Cambrian and Ordovician strata are metamorphosed and contain sparse Tertiary? granitic and andesitic dikes, whereas younger Paleozoic strata are unmetamorphosed and lack intrusive rocks. The Cambrian and Ordovician strata in the map area were originally divided into the following four units by Hyde and Huttrer (1970): the Ordo- vician Pogonip Group undivided, Cambrian "a," Cambrian "b," and Cambrian "undivided" units. These strata were subsequently divided by Camilleri (1988) into eight formations and three informal members, which are shown in the legend on the map. The correlation of these formations was accomplished by observing Cambrian and Ordovician strata described and mapped by: Humphrey (1960) in the Mt. Hamilton area, Kellogg (1963) in the southern Egan Range, Moores et al. (1968) in the southern White Pine Range, and Cebull (1967) and Fryxell (1984) in the southern Grant Range (see correlation chart on the map).

There are six basic Quaternary units. These include alluvialfan surfaces (Qf1, Qf2a, Qf2b, Qf3 and Qal) and pluvial lake deposits (Qp; Fig. 3A). Collectively, the alluvial-fan surfaces reflect a progressive basinward-stepping of depo-centers accompanied by erosion of older deposits (Camilleri et al., 2011). The oldest fan surface, Qf1, is mainly present mantling the pediment developed on Paleozoic basement to the east of the range-front fault 


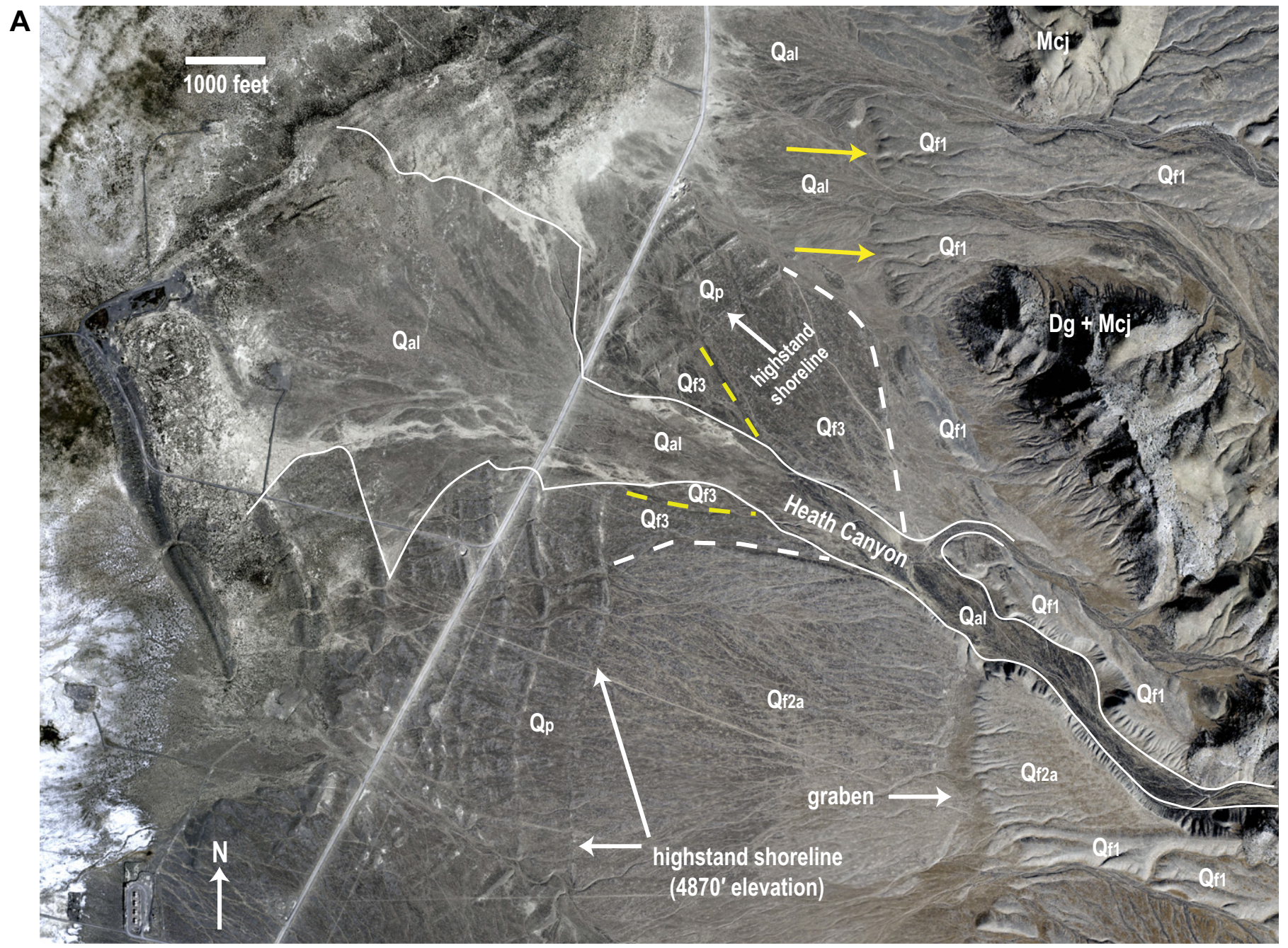

Figure 3 (on this and following page). Photos of Quaternary deposits and range-front fault scarps and cross section through the range-front fault. (A) Aerial photo showing Quaternary deposits and fault scarps around the mouth of Heath Canyon. Modern alluvial deposits (Qal) emanating from the mouth of Heath Canyon are delimited by the solid white line. Unit Qf1 is the oldest alluvial surface and Qf2a is younger than, and incised into, Qf1. Unit Qf3 is incised into Qf2a. Qf3 is present between the white dashed line and Qal in Heath Canyon, and within this area Qf3 is actually a composite surface. The oldest Qf3 is present between the white and yellow dashed lines and a younger Qf3 of limited areal extent is between the yellow dashed line and modern stream deposits (Qal) in Heath Canyon proper. The younger Qf3 surface is incised into the older one. Yellow arrows (top right) point to degraded fault scarp overlapped in part by modern alluvium (Qal). This scarp was probably modified by pluvial erosion prior to overlap by modern alluvium. Photo is from http://seamless.usgs.gov/website/seamless/viewer.htm. (B) Photo of faults that cut the Qf2a surface in the south wall of Heath Canyon. These faults define a graben. The white dashed line in the photo to the left represents the Qf2a surface. View is looking south. The floor of Heath Canyon, which contains unit Qal, is in the foreground and the wall of the canyon provides a cross section through the graben. Locations of faults are shown in yellow. Photo courtesy of Jack Deibert. (C) Map and cross section through the range-front fault around Heath Canyon. Cross section and map are modified after Hulen et al. (1994) and are based on well data from the Grant Canyon and Bacon Flat oil fields as well as surface map data from this study. Hulen et al.'s (1994) map and cross section have been modified to include the range-front fault cutting Quaternary alluvium, which was mapped in this study.

system, which is manifest as the series of normal faults that cut the Quaternary deposits. Qf1 represents a series of fans developed between inselbergs of Devonian and Mississippian strata on the pediment. Qf2a represents a surface incised into Qf1 along Heath Canyon and in a small area in the northernmost part of the map area. Unit Qf2b is primarily present in the hanging wall of the range-front fault south of Heath Canyon. Unit Qf2b contains the same surface as Qf2a but it includes sediment derived from erosion of the fault scarp that cuts the Qf2 surface. Qf3 is a surface incised into Qf2a along Heath Canyon. Unit Qp includes a series of predominantly gravel pluvial shoreline deposits superimposed on older alluvial fan surfaces (cf. map and Fig. 3). The shoreline deposits record an overall regression of the Pleistocene pluvial lake that occupied Railroad Valley. The high-stand shoreline (see dashed blue line on the map and photo in Fig. 3) is at 4870' elevation and is Late Pleistocene in age (Reheis, 1999). 
B
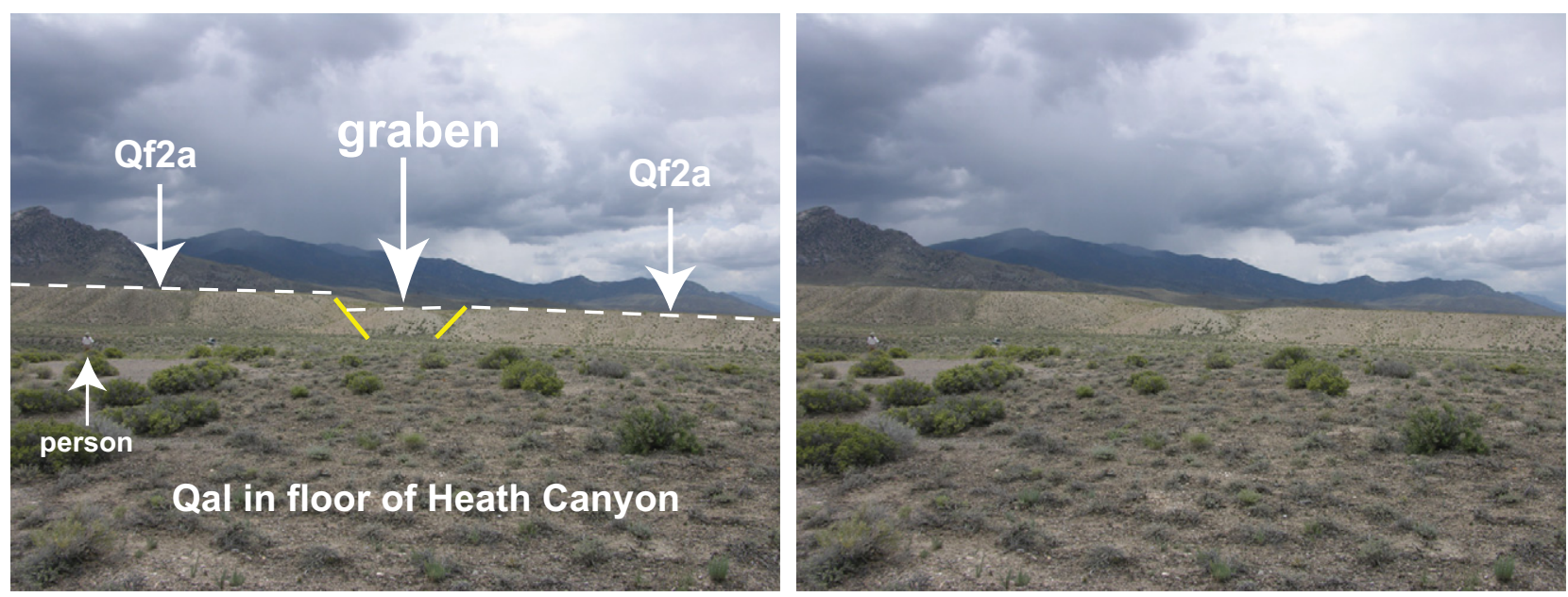

C
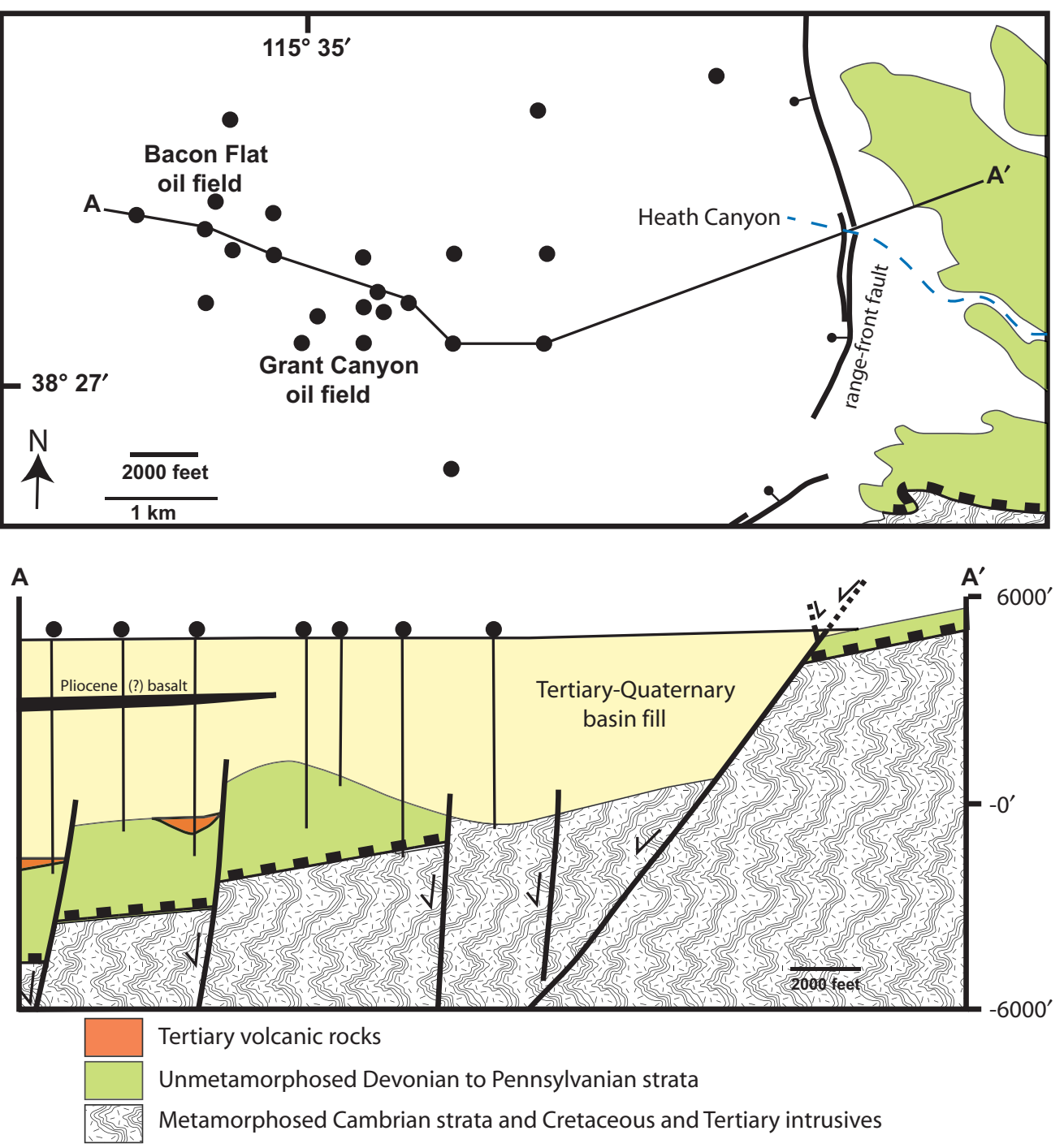

- Well

Lـ Low-angle normal fault \#1

Figure 3 (continued). 
This shoreline postdates incision of the Qf3 surface and is only locally preserved where it is not overlapped by younger Qal deposits. The youngest Quaternary deposits, Qal, consist of modern stream and alluvial fan deposits. The Qal alluvial fan deposits prograded with retrogression of the pluvial lake.

The map area is structurally complex with the most salient features being extensional faults. These include the down-to-thewest range-front fault system with conspicuous fault scarps in Quaternary deposits on the west (Figs. 3A, 3B), and on the east, an arched, imbricate array of six Tertiary low-angle normal faults that dramatically thinned the Paleozoic stratigraphic section (Fig. 4). These low-angle normal faults converge to the west and diverge toward the east, with the greatest amount of extension on the west where unmetamorphosed Mississippian and Devonian strata are juxtaposed atop metamorphosed Cambrian strata (Fig. 4). The Cambrian and Ordovician rocks between these Tertiary low-angle normal faults remarkably preserve a complex Mesozoic metamorphic and contractional history that included development of relatively small-scale east-vergent folds with associated cleavage and overprinting west-vergent thrust faults that die out into faultpropagation folds. The Mesozoic structure and metamorphism that is preserved between the low-angle normal faults is discussed first followed by a discussion of the extensional features.

\section{MESOZOIC FOLDS AND THRUST FAULTS}

Folds and thrust faults are present in various Paleozoic units throughout the map area, but they are relatively small-scale features. The folds and thrusts are sparse in Silurian and younger rocks, which are predominantly thick-bedded dolostone; however, there are several thrust faults that cut Devonian and Mississippian limestone and shale (Lund et al. 1987, 1988; see map). In contrast, small-scale folds and thrust faults abound in thin-bedded Cambrian and Ordovician limestone, argillaceous limestone, and pelite. In Cambrian and Ordovician strata there are two sets of contractional structures. The first and oldest set consists of mesoscopic east-vergent folds $\left(F_{1}\right)$. The second set consists of west-vergent folds $\left(F_{2 X}\right)$ and related thrust faults and a local series of upright folds $\left(\mathrm{F}_{2 y}\right)$. All of the structures in the second set overprint the east-vergent folds of the first set, but the age of west-vergent folds and thrusts relative to the upright folds of the second set is unconstrained.

The Cambrian and Ordovician rocks are divided into a northern and southern structural domain to highlight the differences in structural style and geometry of the contractional structures. The boundary between the two domains is the ridge that separates Beaty and Blair Canyons (Fig. 2). Reference to rocks in the northern or southern domains refers to rocks north or south of this ridge, respectively.

\section{East-Vergent $F_{1}$ Folds and $S_{1}$ Cleavage}

The east-vergent folds $\left(\mathrm{F}_{1}\right)$ are prevalent in the Pogonip Group and Eureka Quartzite in the northern domain and in Cambrian strata in the southern domain (Figs. 5A, 5C, 6A, 6B). These folds range from open to isoclinal and typically contain a spaced axial-planar cleavage $\left(S_{1}\right.$; Fig. 6$)$. The $S_{1}$ cleavage tends to be strong in the hinge regions of folds with bedding commonly transposed. Rare parasitic folds are associated with some of these folds at lower stratigraphic levels. Although local $F_{1}$ fold morphology varies with lithology and bedding character, overall the degree of ductile strain manifest in these rocks generally increases with stratigraphic and structural depth. For example, at higher stratigraphic levels, fold geometry is roughly concentric whereas at lower stratigraphic levels, particularly within thinbedded argillaceous carbonate rock, folds exhibit significant attenuation or boudinage on the limbs and thickening in the hinge regions (Fig. 6B). In addition, in certain parts of the deepest stratigraphic levels, the presence of rootless folds in thin-bedded micaceous fine-grained marble is evidence that bedding is completely transposed.

$F_{1}$ fold axes and intersection lineations $\left(S_{1} X_{0}\right)$ plunge gently in north to north-northwest and south to south-southeast directions (Fig. 7A). $S_{1}$ in rocks of the southern domain, where not overprinted, dips west. $S_{1}$ in rocks of the northern domain, however, dips west on the west side of the map area and dips east on the east side. The poles to $S_{1}$ in the northern domain crudely fall on a great circle: the pole to this great circle suggests broad refolding of the $S_{1}$ cleavage about a north-northwest-trending axis in this area (Fig. 7A). This refolding is reflected in the broad folding of the Ordovician section and the $F_{1}$ axial surfaces in the south wall of Beaty Canyon, which dip steeply to the east on the east and dip gently east on the west (see cross section $\mathrm{B}-\mathrm{B}^{\prime}$ in Fig. 5C).

\section{West-Vergent $F_{2 x}$ Folds, $S_{2 x}$ cleavage, and Thrust Faults}

The east-vergent $F_{1}$ folds and associated $S_{1}$ cleavage are overprinted by small-scale, west-vergent open to tight folds $\left(\mathrm{F}_{2 \mathrm{X}}\right)$ and thrust faults, which indicate a diametric change in vergence. These west-vergent structures are prevalent in Ordovician strata in the northern domain and in Cambrian strata in the southern domain (Fig. 8). The hinges of $F_{2 X}$ folds plunge gently in northnorthwest to north-northeast and south-southwest to southsoutheast directions and therefore are approximately coaxial with hinges of the $F_{1}$ folds (cf. Figs. 7A, 7B). The $F_{2 X}$ folds most commonly developed in the hanging walls of the west-vergent thrust faults (Figs. 8B, 8C, 8D). In the hanging walls of these thrust faults, $S_{1}$ is invariably deformed (Fig. 9 ) and in a few places, $F_{2 x}$ folds can be observed to refold $F_{1}$ folds (Fig. 8C). Minor structures associated with the $F_{2 X}$ folds include (1) a weak mesoscopic axial-planar cleavage $\left(\mathrm{S}_{2 x}\right)$ in carbonate layers, which is only present in a few of the $\mathrm{F}_{2 \mathrm{X}}$ folds, and (2) a strong crenulation lineation $\left(\mathrm{L}_{2}\right.$, Figs. 7B, 9B) in phyllitic layers that is formed by the intersection of $S_{1}$ and $S_{2}$. This lineation is coaxial with $F_{2 x}$ and $F_{1}$ fold axes (cf. Figs. 7A, 7B).

The west-vergent thrust faults in the northern domain are present in the Eureka Quartzite and in underlying Pogonip Group strata. The thrust faults in Eureka Quartzite are small 

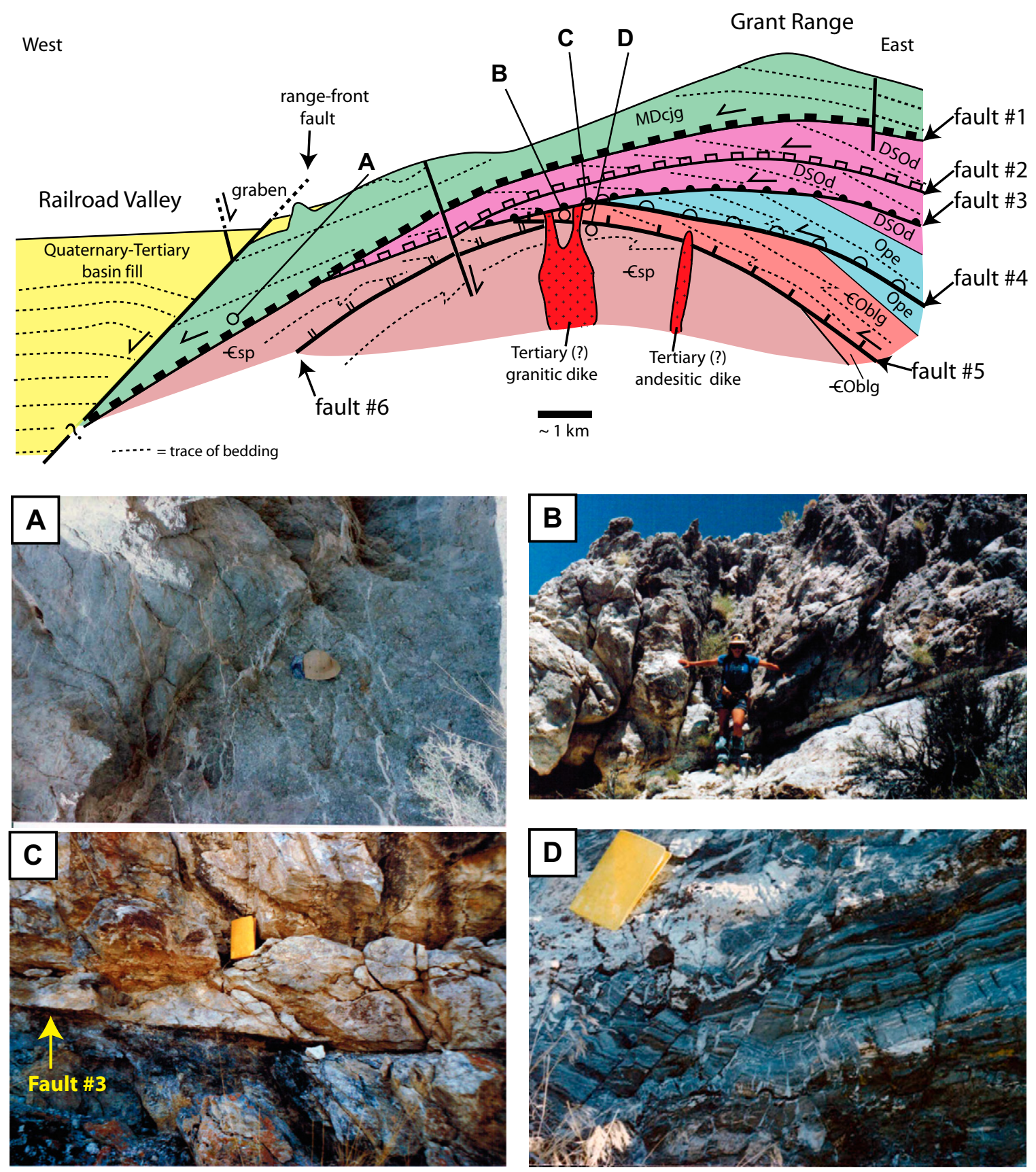

Figure 4. West-east schematic structural cross section through the Grant Range and Railroad Valley and photos of faults and fault rock. The cross section shows the structural location of the rock depicted in the photos. (A) Brecciated Devonian Guilmette Formation adjacent to, and in the hanging wall of, fault \#1 in Beaty Canyon. Note calcite-filled extension veins cutting the fault breccia. Hat for scale. (B) Photo of faulted, fractured and pervasively brecciated Cambrian Little Meadows Formation in the hanging wall of fault \#5 south of western end of Heath Canyon. These rocks form the westernmost tapered end of the fault slice bound by fault \#5 below and the coalescence of younger faults \#1, 2, and 3 above. (C) Photo of fault \#3 on the south side of Blair Canyon. Hanging wall rocks are thoroughly brecciated Silurian Laketown Dolomite and footwall rocks are sheared Cambrian-Ordovician Goodwin Limestone. Notebook in (C) and (D) is 7 inches long. (D) Photo of down-to-the-west mesoscopic listric normal faults in the Pole Canyon Limestone from the north side of Blair Canyon. These faults are in the footwall of fault \#5 in proximity of the fault. MDcjg = Joana Limestone and Chainman Shale (Mississippian) and Guilmette Formation (Devonian) undivided. DSOd = Ely Springs Dolomite (Ordovician), Laketown Dolomite (Silurian), Sevy Dolomite (Devonian), and Simonson Dolomite (Devonian) undivided. Ope = Eureka Quartzite, Lehman Formation, Kanosh Shale, Shingle Limestone, and Parker Spring Formation (Ordovician) undivided. COblg = Goodwin Limestone (Cambrian to Ordovician), Little Meadows formation, and Blue Eagle member (Cambrian) undivided. Csp = Grant Canyon member, Willows Springs member and Pole Canyon Limestone (Cambrian) undivided. 

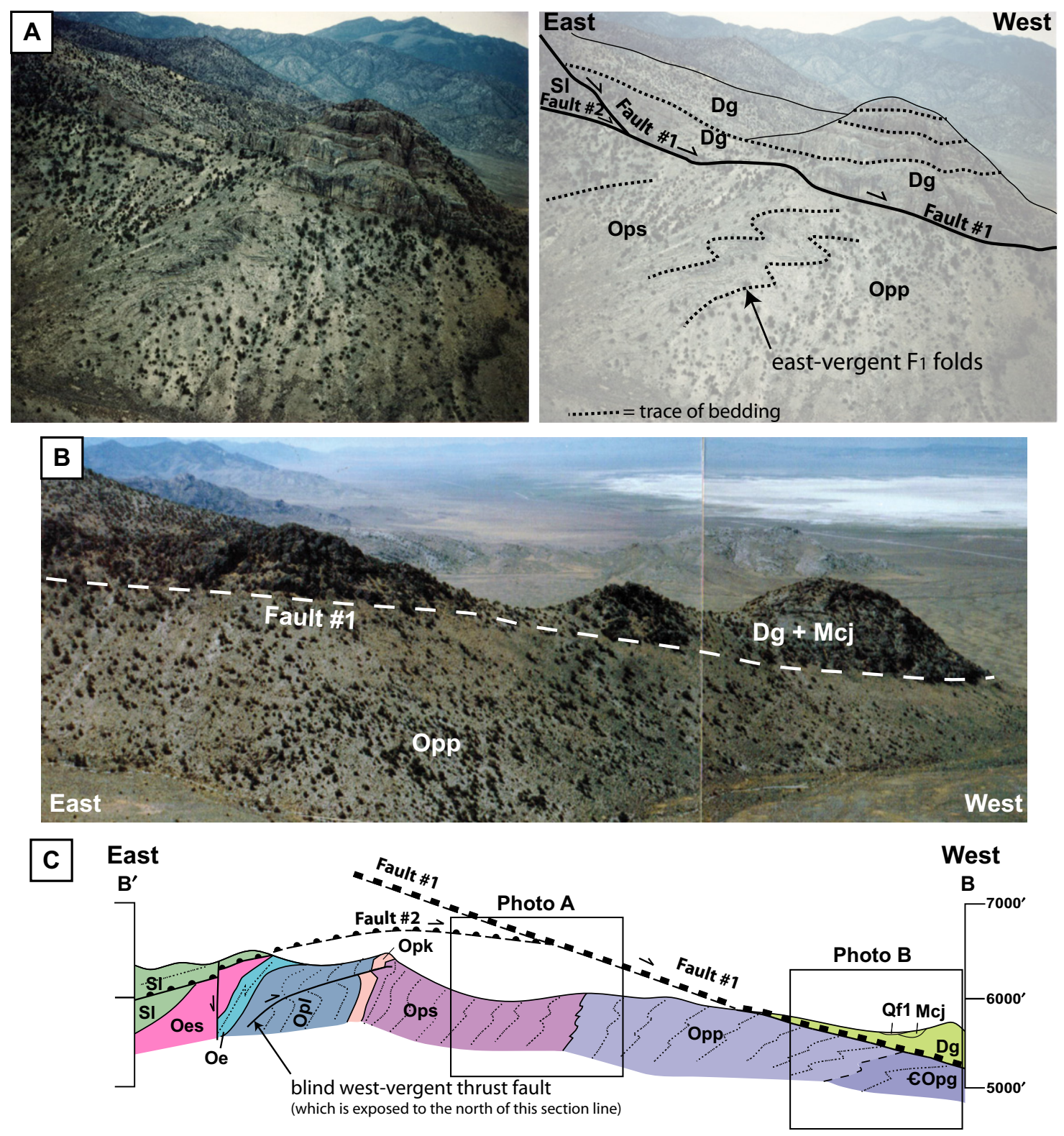

1 kilometer

Figure 5. Photos and cross section of low-angle normal faults \#1 and \#2 and $\mathrm{F}_{1}$ east-vergent folds in Beaty Canyon (northern domain). (A) Photo and line drawing depicting an oblique aerial view (from a helicopter) of the eastern part of the south wall of Beaty Canyon showing faults \#1 and \#2 and $F_{1}$ folds in the Pogonip Group in the footwall of the faults. (B) Photo of the south wall of Beaty Canyon to the west of the photo in (A). View is looking to the south with Railroad Valley playa in the top-right background. (C) Mirror image of cross section B-B' that yields a view looking to the south in proximity of the cross sectional views shown in photos (a) and (b). The cross section shows the relative structural positions of the photos. Ops = Shingle Limestone, Opp = Parker Spring formation; $\mathrm{Sl}=$ Laketown Dolomite; $\mathrm{Dg}=$ Guilmette Formation; Mcj = Chainman Shale and Joana Limestone undivided.

(not mappable at a scale of 1:12,000), have ramp-flat geometry, and fault-bend kink folds in their hanging walls (Fig. 8A). West-vergent thrust faults in the Pogonip Group in this same area, however, are geometrically different. These faults cut $F_{1}$ folds, emplace younger rocks over older rocks, and where displacement across the faults dies out, the $F_{1}$ folds are broadly refolded about the fault tip (shown diagrammatically in crosssections $\mathrm{A}-\mathrm{A}^{\prime}$ and $\mathrm{B}-\mathrm{B}^{\prime}$ on the map). No thrust faults geometrically like those in the Eureka Quartzite occur in the Pogonip Group and vice versa. Although this may be related to rheologic differences between the units, preexisting structure likely exerted some control on thrust geometry in the Pogonip Group. 

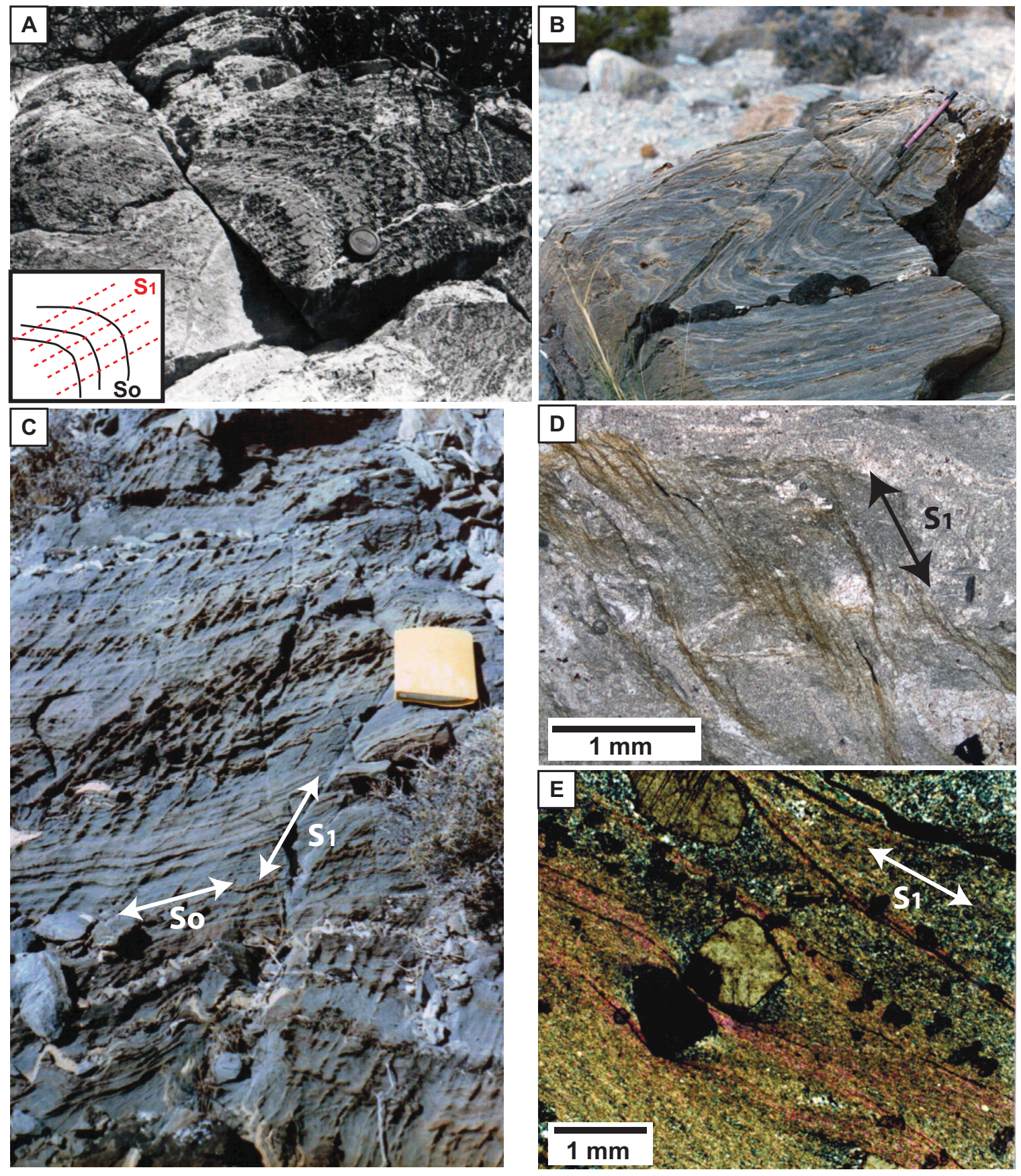

Figure 6. Photos showing east-vergent $F_{1}$ folds and $S_{1}$ cleavage. (A) Hinge region of an $F_{1}$ fold in the Cambrian Willow Springs member. The fold is developed in thin bedded silty limestone and has a strong, spaced axial planar $\mathrm{S}_{1}$ cleavage. Lens cap for scale. (B) Ductile $F_{1}$ fold in fine-grained marble in the Cambrian Willow Springs member. This fold does not have a strong cleavage but instead exhibits attenuation on the limbs and thickening in the hinge of the fold and minor boudinage. Pen for scale. (C) Well-developed spaced axial planar cleavage from the hinge area of an $\mathrm{F}_{1}$ fold in the Pole Canyon Limestone. Notebook is 7 inches long. (D) Photomicrograph of a well-developed, spaced $\mathrm{S}_{1}$ cleavage in a fossiliferous limestone from the Ordovician Shingle Limestone in Heath Canyon. Plane-polarized light. (E) Photomicrograph of $S_{1}$ in phyllite in the Ordovician Parker Spring Formation in Beaty Canyon. White mica, quartz, calcite, and dolomite are the predominant minerals. Mineral with pressure shadows is dolomite. White mica defines the foliation. Crossed polars. 


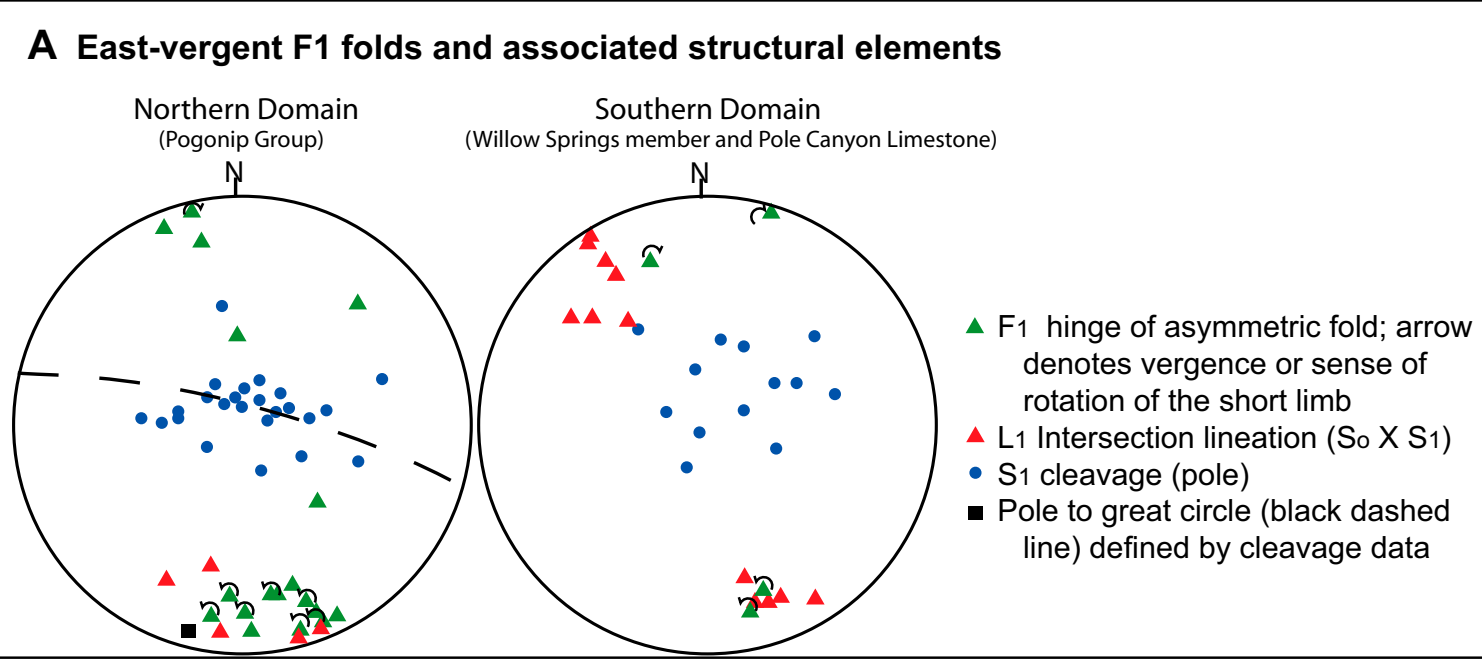

\section{B West-vergent F2x folds and associated structural elements}

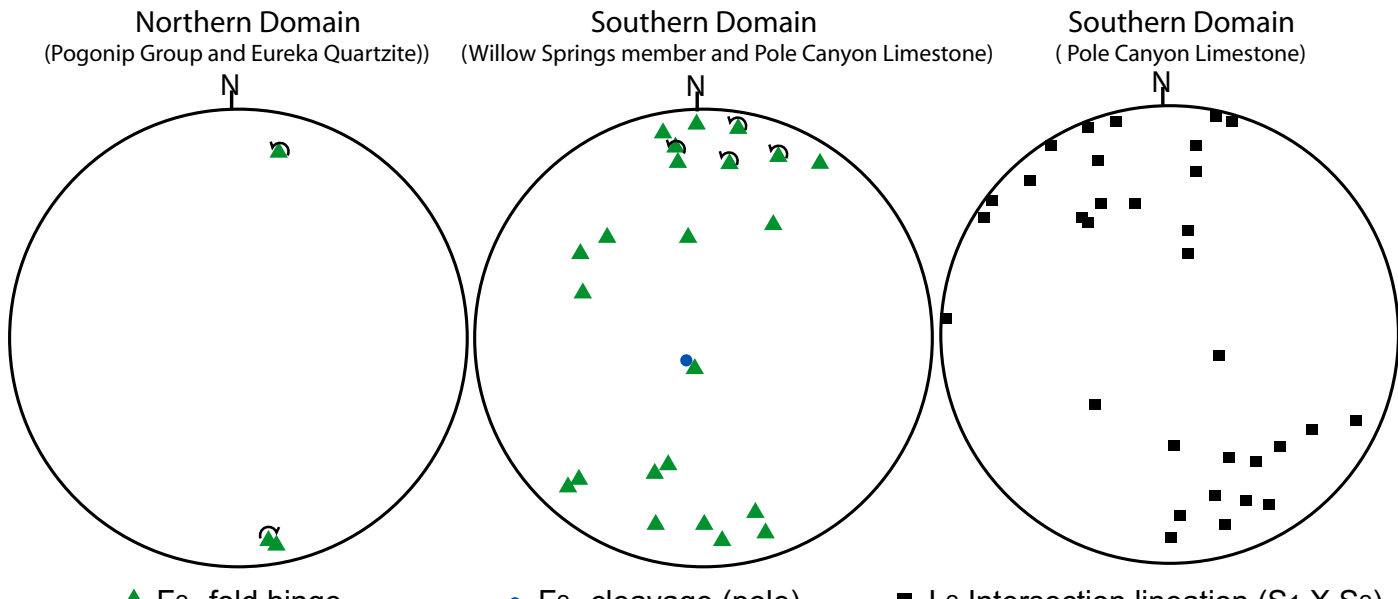

F2x fold hinge

- F2x cleavage (pole)

- L2 Intersection lineation (S1 X S2)

\section{Upright F2y folds and associated structural elements}

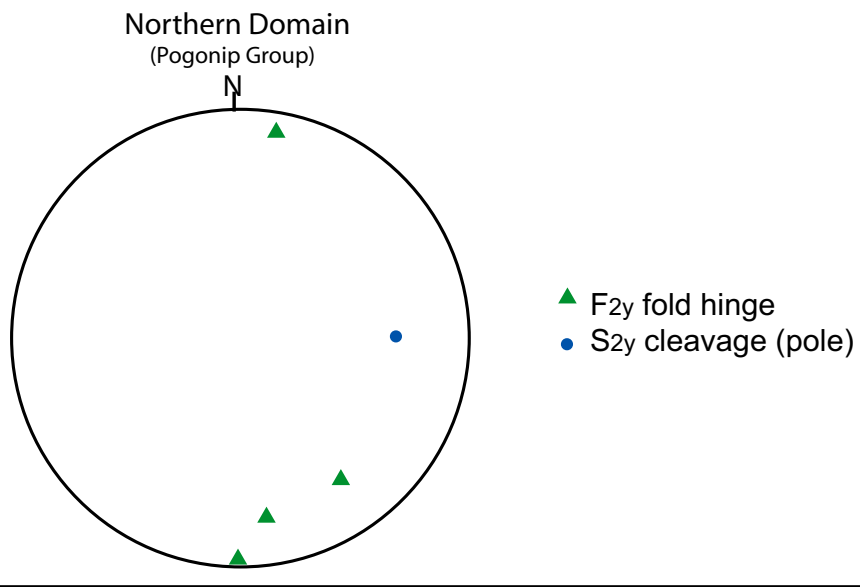

Figure 7. Lower hemisphere stereographic projections of fold axes, intersection lineations and poles to cleavage in metamorphosed Cambrian and Ordovician strata. The intersection lineations in (A) represent the intersection of bedding and cleavage measured on either a cleavage or bedding surface. The intersection lineations in (B) represent the hinges of crenulations (crenulation cleavage). 

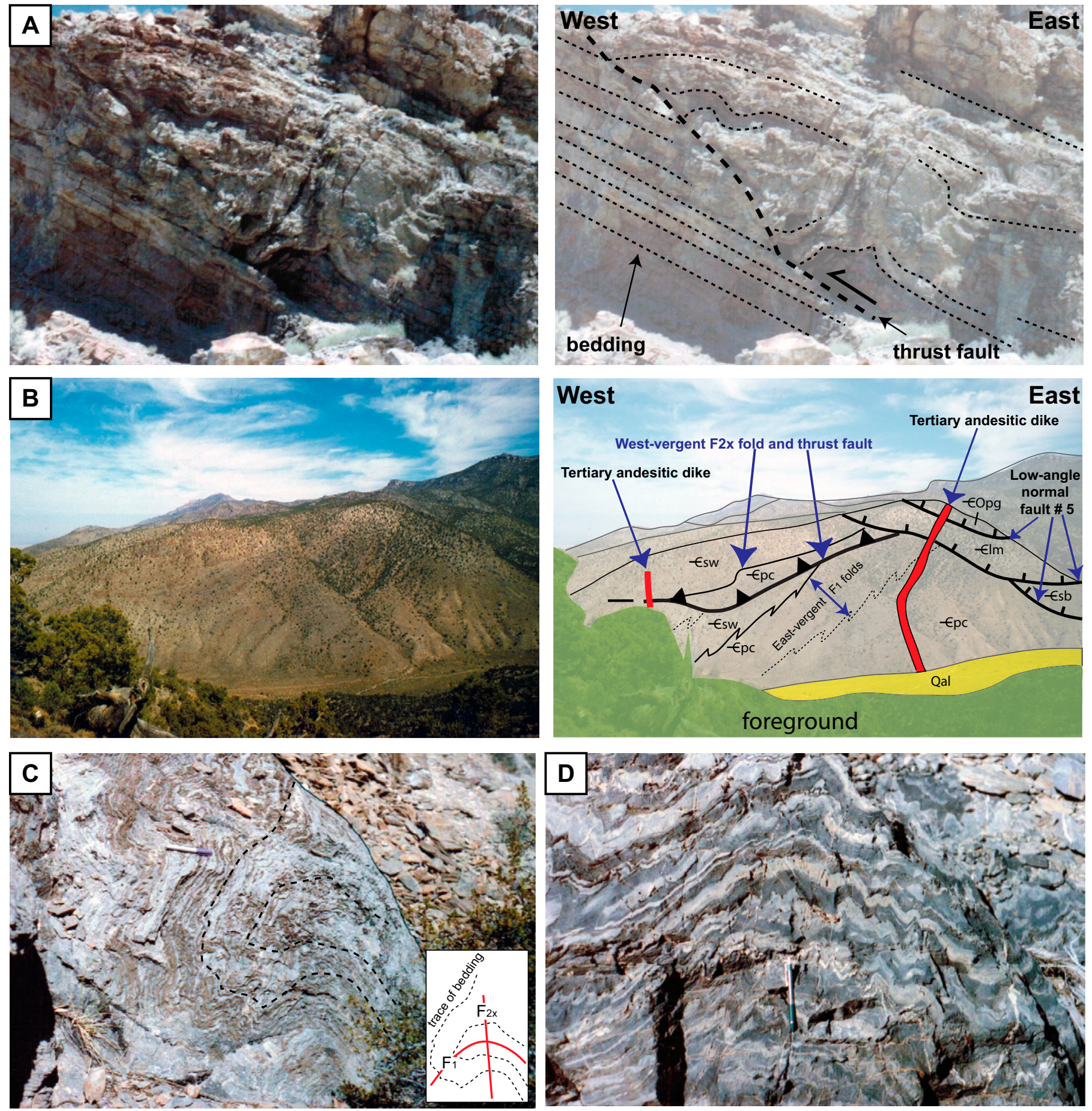

Figure 8. Photos of west-vergent folds $\left(\mathrm{F}_{2 \mathrm{x}}\right)$ and thrust faults. (A) Photo and line drawing of a thrust fault and its deformed hanging wall in the Eureka Quartzite in the northern domain in Beaty Canyon. (B) Photo and line drawing of the north wall of Heath Canyon (view is looking north). The most salient structures in this photo are the west-vergent thrust fault and fold in its hanging wall. They are manifest by a color change at the contact between the Pole Canyon Limestone (dark) and Willow Springs member (lighter). The line drawing also shows the locations of other important structural features (e.g., dikes, low-angle normal faults, and some [not all] $\mathrm{F}_{1}$ folds) that can be found on this hill side but that are not evident at the scale and resolution of the photo. The photos in (C) and (D) show $\mathrm{F}_{2 \mathrm{x}}$ folds in the hanging wall of this thrust. (C) Photo of an $\mathrm{F}_{2 \mathrm{X}}$ fold that refolds an $\mathrm{F}_{1}$ fold in the Pole Canyon Limestone. Pen for scale. (D) Photo of an $\mathrm{F}_{2 \mathrm{x}}$ antiform in the Pole Canyon Limestone. This antiform has parasitic folds that fold boudinaged layers. Boudinage was probably produced during the development of the east-vergent folds. Pen for scale. 

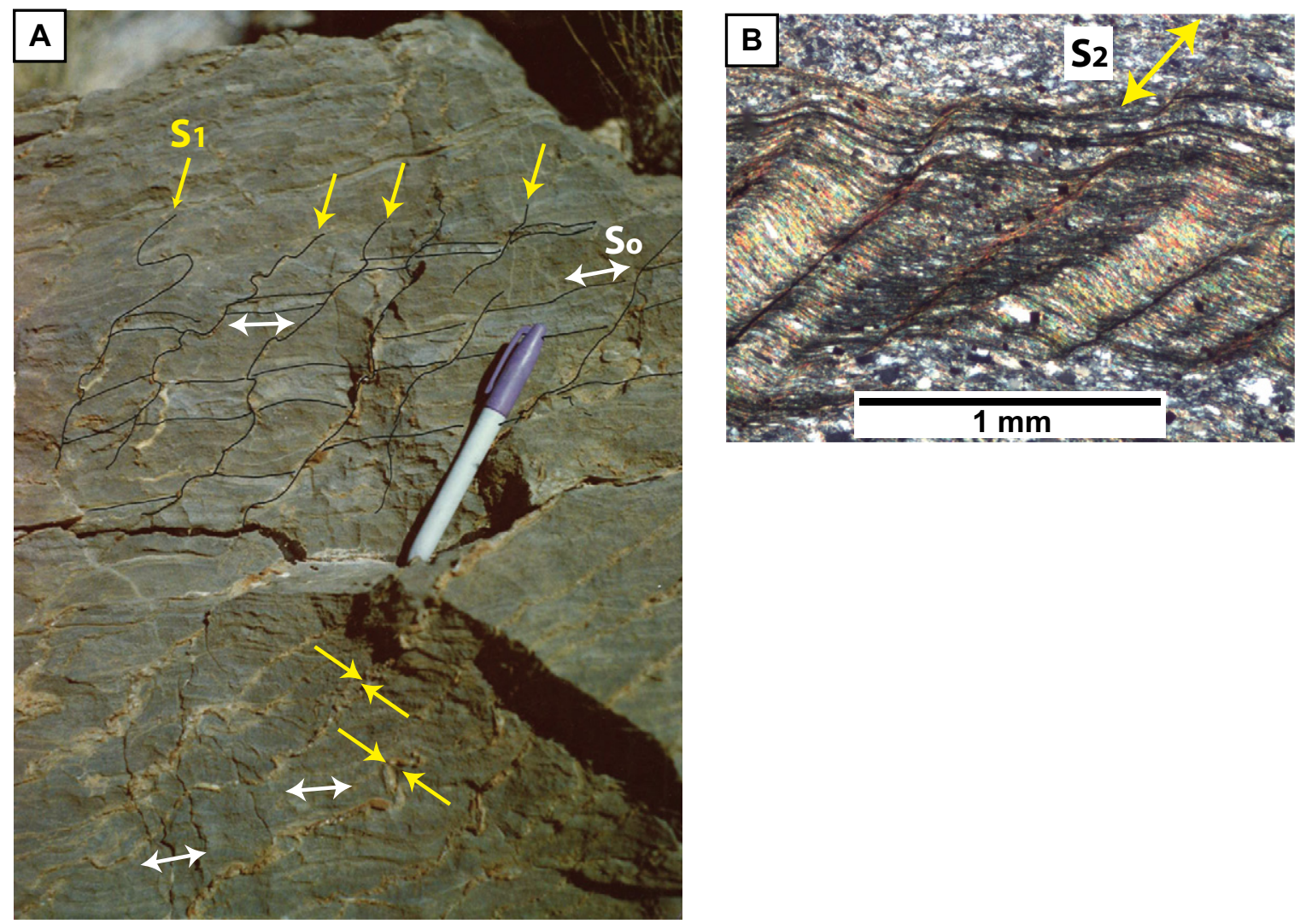

Figure 9. Photos showing structure related to west-vergent deformation. (A) Photo showing a typical example of how a spaced phlogopite-bearing $S_{1}$ cleavage in the Willow Springs member deformed in response to west-vergent deformation. The black lines in the top of the photo highlight the relationship between bedding and a ptygmatically folded $S_{1}$ cleavage. Yellow arrows point to $S_{1}$ and double-headed white arrows show the orientation of the trace of bedding $\left(S_{0}\right)$. The $S_{1}$ cleavage is this rock is a spaced solution seam with a concentration of metamorphic phlogopite. The growth of phlogopite occurred following development of the solution seam during a period of static metamorphism and then was subsequently deformed as bedding was refolded during west-vergent deformation. (B) Photomicrograph of crenulated $S_{1}$ defined by white mica and an associated $S_{2}$ crenulation cleavage in a phyllitic layer in the Ordovician Eureka Quartzite. Crossed polars.

The thrust faults in the Pogonip Group appear to have developed parallel to the strong $\mathrm{S}_{1}$ cleavage and it is likely that the anisotropy imparted by the cleavage provided a plane of weakness that resulted in thrust faults forming parallel to, and reactivating, $S_{1}$.

One thrust fault is exposed in the southern domain. This thrust fault cuts west-dipping strata of the Willow Springs member and Pole Canyon Limestone, emplaces older rocks on younger rocks, and discordantly cuts rocks that contain $F_{1}$ folds (see Fig. 8B; this relationship is shown in cross-section E-E' on the map). $F_{2 X}$ folds are present in the hanging wall of this fault (Figs. 8C, 8D) as well as in other areas in Heath Canyon where they may be related to blind thrust faults.

\section{Upright Folds and $S_{2 y}$ cleavage}

In the northern domain, on the northwestern side of Beaty Canyon, small-scale upright symmetrical folds $\left(\mathrm{F}_{2 y}\right)$ refold $\mathrm{F}_{1}$ folds in the Pogonip Group, but their relationship to $F_{2 X}$ folds is not known. The $\mathrm{F}_{2 \mathrm{y}}$ folds are small in amplitude and wavelength and have poorly developed axial-planar cleavage $\left(\mathrm{S}_{2 y}\right)$. The folds are approximately coaxial with $F_{1}$ and $F_{2 x}$ folds (Fig. 7C).

\section{METAMORPHISM DURING FOLDING AND THRUST FAULTING}

Cambrian and Ordovician strata contain minerals indicative of greenschist facies metamorphism. Diagnostic metamorphic minerals in Ordovician pelite and impure carbonate are sericite and chlorite, and in lowermost Cambrian strata, are biotite in pelite and phlogopite and amphibole (pargasite?) in metacarbonate rocks (Fig. 10). These assemblages suggest that Ordovician strata are in the chlorite zone and lowermost Cambrian strata are in the biotite zone. Three sequential phases of metamorphism are collectively recorded in these rocks. The first phase consisted of a pulse of regional (synkinematic) metamorphism, the second involved static metamorphism, and the third phase was synkinematic. 
A

Figure 10. (A) Table listing diagnostic metamorphic minerals in Cambrian and Ordovician strata and photomicrographs of amphibole in the Willow Springs member. Shaded (gray) areas indicate unit has no diagnostic metamorphic minerals. The photomicrograph in (B) shows a brown pholgopite porphyroblast (outlined by white dashed line) that has been partially replaced by amphibole (areas of high birefringence). The photomicrograph in (C) shows an amphibole (outlined by white dashed line) that has almost completely replaced a pholgopite porphyroblast. Only a small amount of pholgopite (brown) remains in the center. The photomicrograph in (B) is in crossed polars and in (C) is in plane polarized light.

\begin{tabular}{|c|c|c|c|c|}
\hline & \multicolumn{2}{|c|}{ Formation } & $\begin{array}{l}\text { Metamorphic minerals } \\
\text { in pelite/metapelite* }\end{array}$ & $\begin{array}{c}\text { Metamorphic minerals in } \\
\text { impure carbonate/ } \\
\text { metacarbonate rock* }\end{array}$ \\
\hline \multirow{6}{*}{ 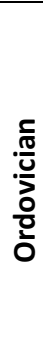 } & \multicolumn{2}{|c|}{$\begin{array}{l}\text { Ely Springs Dolomite and younger } \\
\text { formations }\end{array}$} & & \\
\hline & \multicolumn{2}{|c|}{ Eureka Quartzite } & Sericite in phyllite or argillite & \\
\hline & \multirow{5}{*}{ Pogonip Group } & $\begin{array}{l}\text { Lehman } \\
\text { Formation }\end{array}$ & & \\
\hline & & Kanosh Shale & Sericite in argillite & Sericite in limestone \\
\hline & & $\begin{array}{c}\text { Shingle } \\
\text { Limestone }\end{array}$ & Sericite in phyllite or argillite & Sericite in limestone \\
\hline & & $\begin{array}{l}\text { Parker Spring } \\
\text { Formation }\end{array}$ & Sericite in phyllite or argillite & Sericite and chlorite in limestone \\
\hline \multirow{6}{*}{$\frac{\frac{\pi}{0}}{\frac{\pi}{2}}$} & & $\begin{array}{l}\text { Goodwin } \\
\text { Limestone }\end{array}$ & & \\
\hline & \multicolumn{2}{|c|}{ Little Meadows Formation } & & \\
\hline & \multirow{3}{*}{$\begin{array}{l}\text { Sidehill Spring } \\
\text { formation }\end{array}$} & $\begin{array}{c}\text { Blue Eagle } \\
\text { member }\end{array}$ & & $\begin{array}{l}\text { White mica and tourmaline in } \\
\text { limestone or fine-grained marble }\end{array}$ \\
\hline & & $\begin{array}{l}\text { Grant Canyon } \\
\text { member }\end{array}$ & $\begin{array}{l}\text { White mica, chlorite, and } \\
\text { ilmenite? ( altered to } \\
\text { leucoxene) in phyllite }\end{array}$ & No data \\
\hline & & $\begin{array}{l}\text { Willow Spring } \\
\text { member }\end{array}$ & & $\begin{array}{l}\text { Phlogopite, amphibole* } \\
\text { (pargasite?), chlorite, and white } \\
\text { mica in fine-grained marble. } \\
\text { *amphibole partially replaces } \\
\text { phlogopite (see photos below) }\end{array}$ \\
\hline & \multicolumn{2}{|c|}{ Pole Canyon Limestone } & $\begin{array}{l}\text { Biotite, white mica, and } \\
\text { chlorite in phyllite or schist }\end{array}$ & $\begin{array}{l}\text { Phlogopite, chlorite, and white } \\
\text { mica in fine-grained marble. }\end{array}$ \\
\hline
\end{tabular}
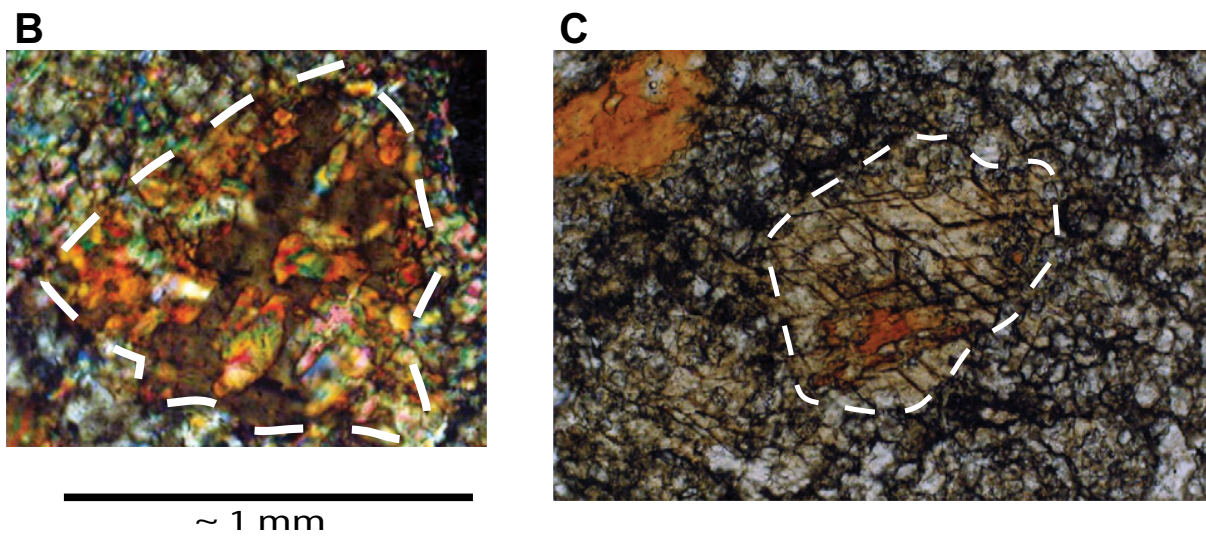

The first regional phase of metamorphism began during development of the east-vergent folds and is manifest by the growth of white mica synchronous with the development of the $S_{1}$ cleavage (Fig. 6E). The second phase of metamorphism post-dates development of the east-vergent folds and is characterized by metamorphic minerals with static textures such as randomly oriented mica and amphibole porphyroblasts. This is especially evident in the Middle Cambrian Willow Springs member wherein phlogopite is randomly oriented within the $S_{1}$ cleavage (solution seam) and in places crosscuts the cleavage boundaries (Figs. 11A, 11B). This observation indicates that metamorphism continued after the cessation of east-vergent deformation during an apparent period of tectonic quiescence.
Rocks with the static textures are most abundant in stratigraphically lowest Cambrian rocks and are lacking in stratigraphically higher rocks. Conversely, synkinematic textures associated with $F_{1}$ folds are best preserved in stratigraphically higher rocks and are less apparent in stratigraphically lower rocks where the effects of static metamorphism are most apparent. In addition, the second phase of metamorphism also reflects a metamorphic peak in that the highest grade metamorphic mineral, amphibole, which replaced pholgopite porphyroblasts, grew during the static phase (Figs. 10B, 10C).

The development of the west-vergent structures post-dates static metamorphism of the second phase. This inference is based on the observation that static phlogopite or biotite porphyro- 
blasts in rocks affected by west-vergent deformation are kinked, sheared, and in places exhibit undulose extinction, subgrain development or less commonly recrystallization (Figs. 11C, 11D). The preservation of the aforementioned deformation microstructures suggests that subsequent to west-vergent deformation, there was insufficient temperature to allow for complete annealing of deformed phlogopite/biotite. The third, regional phase of metamorphism accompanied development of the west-vergent folds and is manifest by localized growth of oriented white mica and chlorite (rare) in $\mathrm{S}_{2}$ (Fig. 9B).

\section{CORRELATION, AGE, AND ORIGIN OF CONTRACTIONAL FEATURES AND METAMORPHISM}

\section{Correlation and Age of Thrust Faults and Folds}

Although the Mesozoic contractional features and metamorphism in the map area can by dated relatively by cross cutting relationships, there are no numerical age constraints. However, some of the structural and metamorphic features are similar to those that are constrained to predate the $86 \mathrm{Ma}$ Troy pluton south of the map area around Troy Canyon (Fig. 1C). For example, Fryxell (1984) indicates that the Timber Mountain anticline predates the 86 Ma pluton and contains mesoscopic folds whose hinges trend NE and SSW to SSE, which is similar to hinges of the east-vergent folds in the map area (e.g., Fig. 7A). By inference, the mesoscopic east-vergent folds in the map area likely represent parasitic folds on the upright limb of this anticline and hence can be inferred to predate 86 Ma. Furthermore, Fryxell (1984) shows the pluton cutting a small-scale, east-dipping, westvergent thrust fault. Assuming that the west-vergent thrusts in the map area are genetically related to the one mapped by Fryxell (1984), they predate $86 \mathrm{Ma}$ as well (Fig. 12).

Fryxell (1991) and Taylor et al. (2000) note that the Timber Mountain anticline and related mesoscopic folds formed in the hanging wall of, and are genetically related to, the Schofield thrust (Fig. 1C), which has a ramp geometry. Assuming that the contractional structures in the map area also formed above a genetically related thrust ramp suggests that the west vergent structures are back-folds and back-thrusts, which are common to thrust ramp settings (e.g., Serra, 1977). Figure 12B-12D schematically shows an example of a possible pre-extension geometry of contractional structures wherein the rocks in the map area formed part of the internally deformed hanging wall above a thrust ramp. Figure 12D shows the development of the east-vergent folds in the hanging wall of the thrust and Figure 12B shows their subsequent overprinting by back thrusting and folding. The development of west-vergent back-folds and thrusts above a ramp would not be unusual because to the south of the map area, in the Quinn Canyon Range (Fig. 1B), Bartley and Gleason (1990) report that the hanging wall of the east-directed Sawmill thrust fault contains a series of west-vergent back-folds and back-thrusts.

\section{Correlation and Age of Metamorphism}

In the Troy Canyon area Fryxell (1988) indicates that two phases of metamorphism are recorded in Cambrian strata. The first phase involved a pulse of regional metamorphism during folding of the Timber Mountain anticline. The second phase followed folding and involved static metamorphism. Fryxell (1988) notes that the formation of the Timber Mountain anticline and most of the metamorphism took place prior to the intrusion of the $86 \mathrm{Ma}$ pluton. The sequence of deformation and metamorphism documented by Fryxell (1988) to the south is similar to that discussed in this paper and therefore the thrust faulting, folding and metamorphism in the map area probably pre-date 86 Ma (Fig. 12). Fryxell (1984, 1988, 1991) attributes metamorphism to burial by overlying thrust sheets with some contribution of heat by the Troy pluton. The origin of static metamorphism in the map area is not clear, but heat derived from a Mesozoic pluton(s) at depth may have driven static metamorphism. Figure 12C-12D illustrates this possibility with regional metamorphism accompanying formation of the east-vergent folds (Fig. 12D) followed by a period of possible tectonic quiescence with pluton emplacement and consequent static metamorphism (Fig. 12C).

\section{CENOZOIC EXTENSIONAL STRUCTURES}

Extensional structures consist of the range-front fault system that cuts Quaternary alluvial deposits and the series of low- to high-angle normal faults in Paleozoic strata. The faults in Paleozoic strata can be divided into two distinct geometric sets: (1) low-angle normal faults ("class 1" faults of Camilleri, 1992), and (2) minor mesoscopic and high-angle normal faults ("class 2" faults of Camilleri, 1992). Overall, these faults are predominantly characterized by brecciation and hence are brittle, although a few of the structurally lowest low-angle faults have associated ductile fault rock. The normal faults provided pathways for circulating hydrothermal fluids that, in places, resulted in intense alteration of rock paralleling the faults.

\section{Geometry and Kinematics of Low-angle Normal (Class 1) Faults}

Six major low-angle normal faults are present within the map area (see Fig. 4 and the map). From youngest to oldest the faults are labeled \#1 through \#6, respectively. These faults are broadly arched about north- to northwest-trending axes, and collectively they form a distinctive geometric pattern. Several generalizations can be made to characterize this geometry (Camilleri, 1992; Fig. 4):

(1) The low-angle normal faults omit stratigraphic section.

(2) Cross-cutting relationships indicate that each structurally higher low-angle normal fault cuts the one(s) below it and therefore is younger (Fig. 12). 
(3) Because metamorphic grade, and in general the degree of ductile strain, dies out stratigraphically upwards, the older faults juxtapose less metamorphosed/deformed rocks over more metamorphosed/deformed rocks, and the youngest fault juxtaposes younger, brittlely deformed unmetamorphosed rocks over older, ductilely deformed metamorphosed rocks.

(4) Bedding-to-fault angles are generally in the range of $5^{\circ}$ to $15^{\circ}$.

(5) Where a fault dips the east, bedding above and below the fault tends to dip more steeply east than the fault; where a fault dips west, bedding generally dips less steeply west than the fault or locally dips gently east.

(6) Although offset across the low-angle normal faults can't be observed in the field, faults \#1through \#4 geometrically appear to be top-to-the-west (hanging wall has moved to the west relative to the footwall; see Fig. 4A). The kinematics of faults \#5 and \#6 are poorly constrained.

(7) Where low-angle normal fault slices taper, near where the faults intersect, intervening rocks tend to be remarkably attenuated by small-scale, high- to low-angle faults (mesoscopic extensional faults), and where these intervening rocks are dolostone they tend to be pervasively brecciated and fractured. Away from the tapered end of a fault slice, where the thickness of a fault slice increases, rocks lack such pervasive deformation and earlier Mesozoic structures and metamorphic fabrics are well preserved.

These observations are based collectively on the character of each fault and its crosscutting relationships with other faults, which are described below.

Fault \#1. The youngest low-angle normal fault is fault \#1, which cuts down-section to the west and juxtaposes Devonian Guilmette Formation and Mississippian Joana Limestone on top of older Cambrian to Devonian rocks. Bedding in the hanging wall of the fault is generally west-dipping and nearly parallel to the fault (Fig. 5A). Fault \#1 dominantly dips to the west, however to the east, the dip of the fault shallows, and to the east of the map area the geologic map of Lund et al. (1987) shows that the fault begins to dip very shallowly $\left(10^{\circ}\right.$ or less) to the east, which indicates that the fault is broadly arched. Fault \#1 cuts the structurally underlying fault \#2.

Fault \#2. Fault \#2 cuts down-section to the west in both its hanging wall and footwall. In the eastern part of the map area it juxtaposes Devonian Sevy and Simonson dolomites on top of Silurian Laketown Dolomite whereas to the west, as it cuts down section, it juxtaposes Sevy and Simonson dolomite, Silurian Laketown Dolomite, and Ordovician Ely Springs Dolomite on top of rocks as old as Ordovician to Cambrian (e.g., see cross section $\mathrm{A}-\mathrm{A}^{\prime}$ on the map). In the eastern part of the map area, where considerable thickness of the hanging wall of fault \#2 is preserved, bedding in the hanging wall and footwall dip more steeply east than the fault indicating a top-to-west-sense of slip across the fault. In the western part of the map area where fault \#2 is in proximity of being cut by fault \#1, rocks in the hanging wall of fault \#2 tend to be thoroughly brecciated and bedding is not discernible. Fault \#2 is broadly arched and this relationship is best observed at the northern end of the map area. Here, the fault dips east at its easternmost exposure and to the west it dips west. Fault \#2 cuts the structurally underlying fault \#3 and is cut by the overlying fault \#1 (see cross-section $\mathrm{A}-\mathrm{A}^{\prime}$ on the map).

Fault \#3. Fault \#3 juxtaposes the Ordovician Ely Springs Dolomite and Silurian Laketown Dolomite on top of older Cambrian and Ordovician rocks (Fig. 4C). Fault \#3 is broadly arched about a northwest-trending axis (Fig. 13). The maximum dip on the fault is $\sim 17^{\circ}$ east (attitude derived trigonometrically from contouring the fault plane) in the eastern part of the map area. In this area, bedding in the hanging wall of the fault dips an average of $25^{\circ}$ east and in the footwall it dips an average of $35^{\circ}$ east indicating that the fault cuts down-section to the west in both the hanging wall and footwall, which requires a top-to-the-west sense-of-slip for the fault. This relationship is best observed where fault \#3 intersects Beaty and Heath Canyons along the eastern margin of the map area and is shown in cross-sections $\mathrm{B}-\mathrm{B}^{\prime}$ and $\mathrm{E}-\mathrm{E}^{\prime}$ on the map (see also Fig. 4). In addition, on the north side of Beaty Canyon, a sliver of Eureka Quartzite excised from the footwall has been brittlely "smeared" out and transported to the west along fault \#3, which also indicates a top-to-the-west sense of shear. Fault \#3 cuts the structurally underlying fault \#4 (see cross-section D-D') and is cut by the overlying fault \#2 (see cross-section A-A").

Fault \#4. Fault \#4 is only exposed from Blair Canyon to the south side of Heath Canyon where it lies structurally above fault \#5 and juxtaposes the Ordovician Parker Spring Formation over the Cambrian-Ordovician Goodwin Limestone. There are no exposed cross-cutting relationships between this fault and fault \#5 so relative age relationships are unknown, however, fault \#4 is cut by and therefore older than fault \#3.

Figure 11. Examples of the relationship between deformation and metamorphism as exemplified by fine-grained micaceous calcite marble of the Cambrian Willow Spring member. (A) Photo and line drawing of spaced $S_{1}$ cleavage and bedding in the Willow Springs member in the hanging wall of the thrust fault on the north side of Heath Canyon. Cleavage weathers out into relief and is composed of coarse-grained micas. Pen for scale. (B) Photomicrograph and line drawing of the $S_{1}$ cleavage shown in photo (A). Mineralogy is phlogopite and calcite, with variable hydrothermal alteration of phlogopite to chlorite. This photomicrograph shows a fine penetrative cleavage that is parallel to the large cleavage (solution seam) in the center. In the solution seam, micas tend to be randomly oriented and in places crosscut the cleavage boundary (the larger micas are shown in gray in the line drawing), indicating static porphyroblast growth following development of the $S_{1}$ cleavage. Note that the large phlogopite porphyroblast in the center of the seam is kinked, which is typical in rocks that are overprinted by west-vergent deformation. Section cut perpendicular to intersection lineation $\left(\mathrm{S}_{1} \times \mathrm{S}_{\mathrm{o}}\right)$. Crossed polars. (C) and (D) show photomicrographs of statically grown phlogopite porphyroblasts that were deformed during west-vergent deformation. (C) is an example from an $F_{2 x}$ fold that refolds an $F_{1}$ fold in the hanging wall of the thrust fault in Heath Canyon. Large, deformed porphyroblast with kink bands in the center in photo (C) was formerly one grain. (D) is an example from Blair Canyon. Crossed polars. 

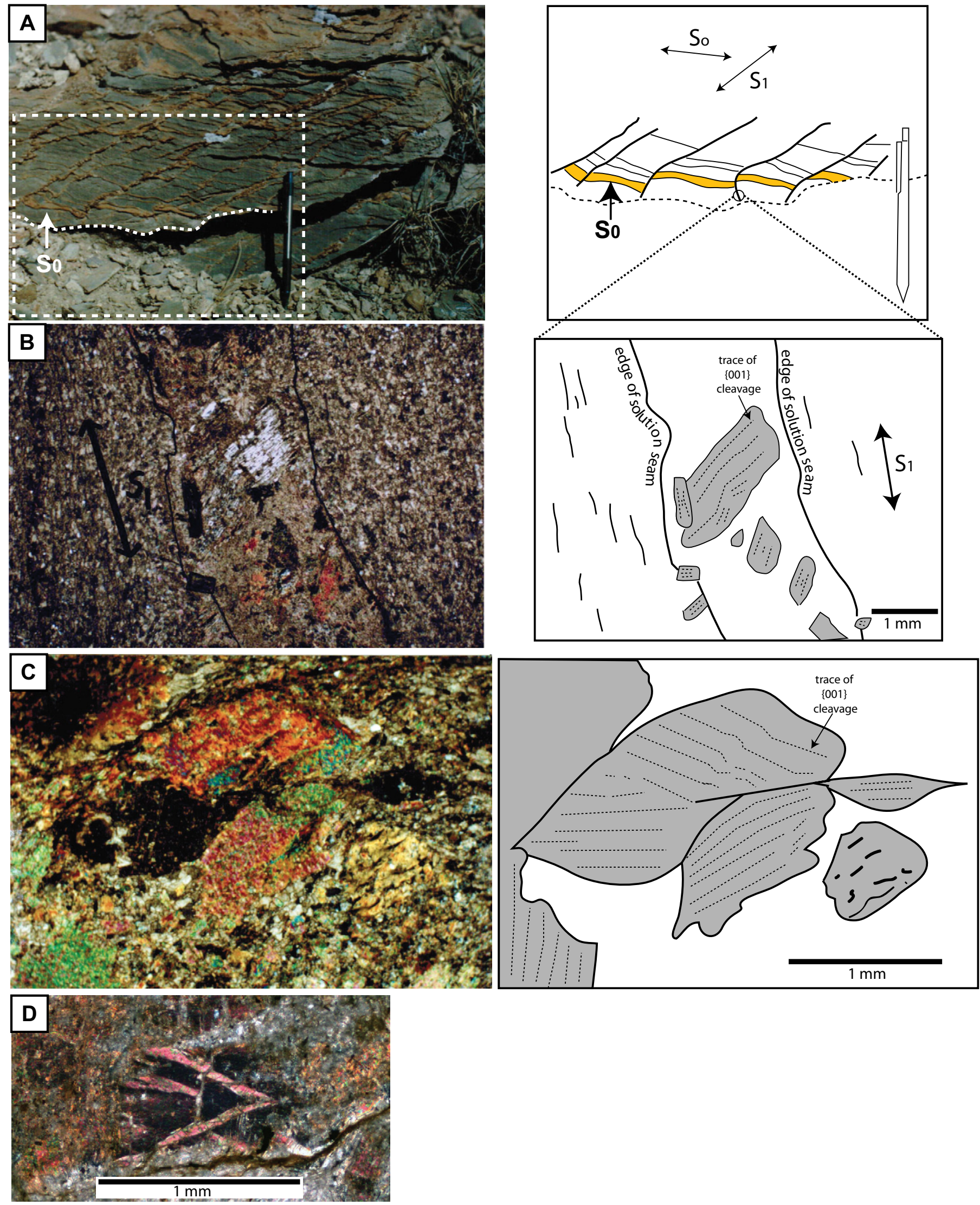
A

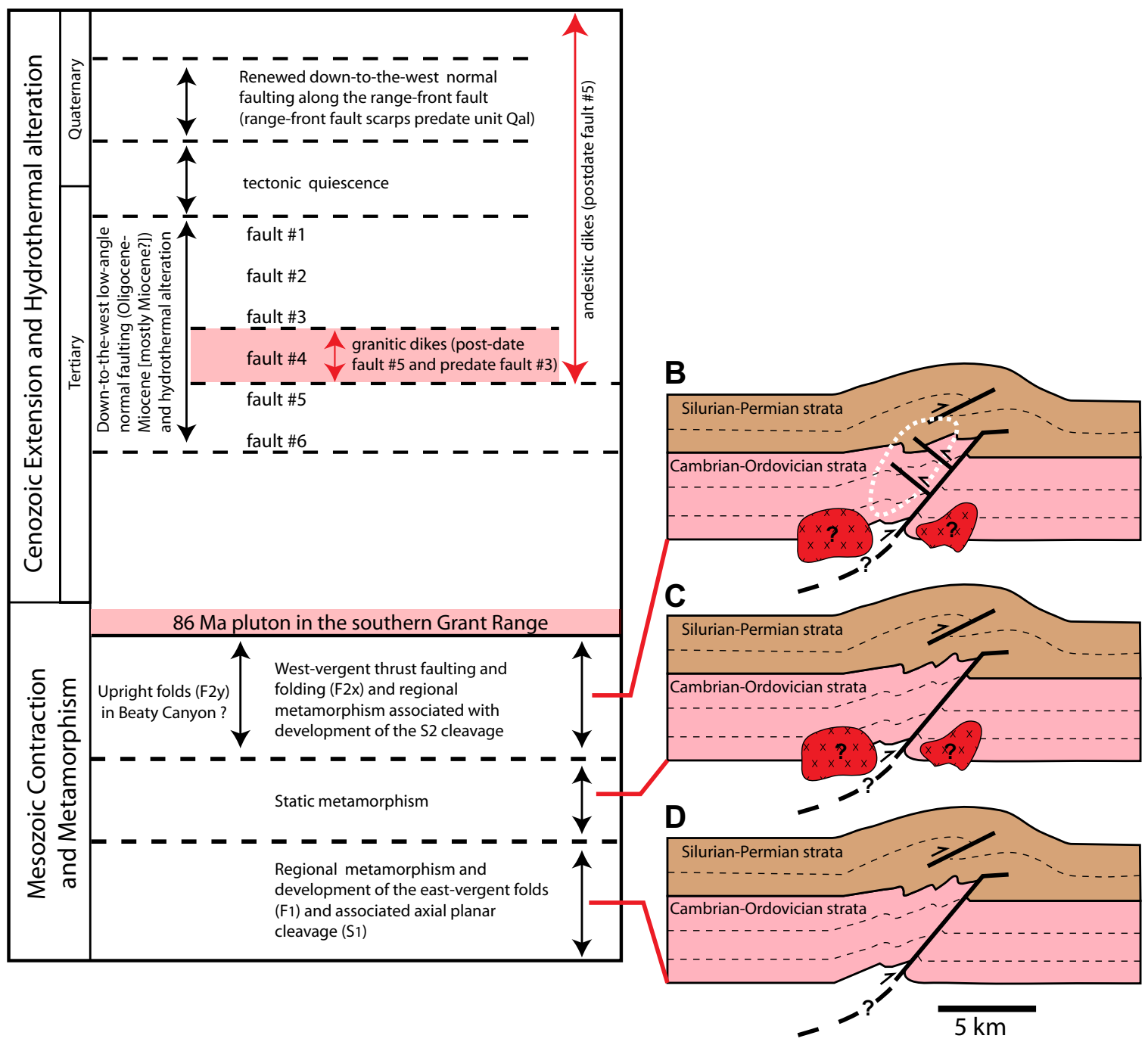

Figure 12. Diagrams summarizing the relative ages of metamorphism, contractional and extensional deformation, and hydrothermal alteration. (A) Chart highlighting relative age constraints of structures. (B, C, D) Sketch illustrating the possible origin of contractional and metamorphic features in the map area. In (D) the east-vergent folds and associated regional metamorphism developed in a ramp anticline, which was then ensued by a period of tectonic quiescence, magmatism (?), and static metamorphism in (C). Static metamorphism was then followed by development of west-vergent back-thrusts and back-folds in (B). White dotted line in (B) outlines rocks currently extensionally dismembered in the map area. Modified from Camilleri (1992).

Fault \#4 is broadly arched and its overall geometry appears to be similar to that of the structurally underlying fault \#5 (see structure contour map of fault \#5 in Fig. 13). In Heath Canyon, fault \#4 dips $\sim 24^{\circ}$ northeast (attitude derived trigonometrically from contouring the fault plane) whereas to the north in the Blair Canyon area, the dip shallows and the fault begins to dip northward (see cross-section C- $\mathrm{C}^{\prime}$ on the map). In Heath Canyon, bedding in the hanging wall dips an average of $\sim 35^{\circ}$ east and bedding in the footwall dips $17^{\circ}$ to $38^{\circ}$, but in proximity of the fault, the dip generally exceeds that of the fault. This is exemplified $\sim 1.5$ $\mathrm{km}$ south of Heath Canyon where fault \#4 is well exposed. Here, it can be observed that strata above and below the fault dip more steeply eastward than the fault. These geometric relationships indicate that fault \#4 cuts down section to the west in both its hanging wall and footwall and that the sense of slip is top-to-the-west (see cross-section E-E' on the map and Fig. 4).

Fault \#5. Fault \#5 is only exposed south of Beaty Canyon where most of it constitutes a zone of closely spaced faults separating thin fault-bounded slices of the Upper Cambrian Blue Eagle member, Little Meadows formation and Pole Canyon Limestone. This closely spaced network of faults appears to merge into a single fault at the base of the Blue Eagle member 
Fault \# 3

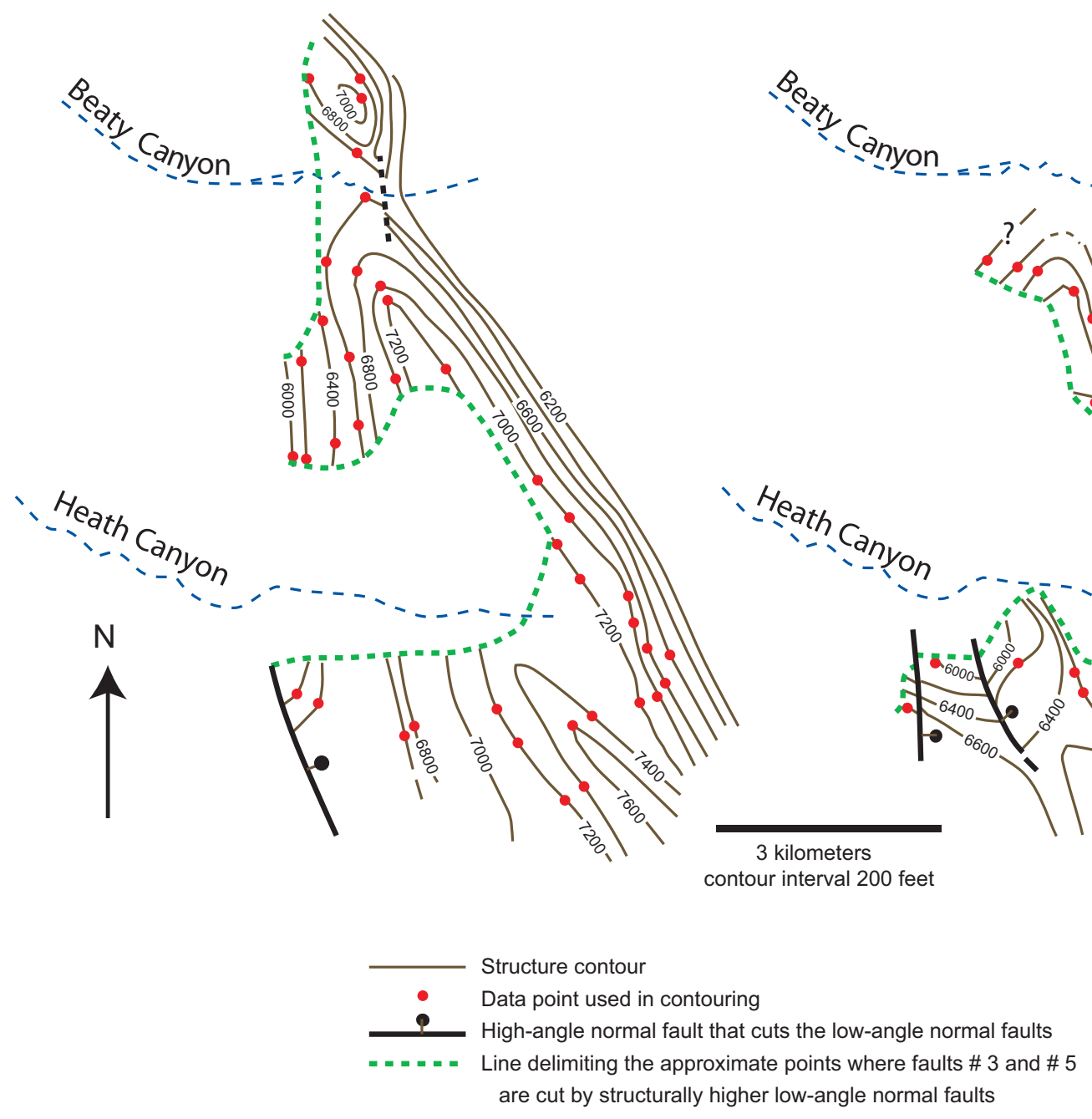

\section{Fault \# 5}

Figure 13. Structure contour maps of low-angle normal faults \#3 and \#5. Modified from Camilleri (1988, 1992). to the southwest of Heath Canyon (see cross section $\mathrm{E}-\mathrm{E}^{\prime}$ ). The hanging wall above the fault zone is composed of undeformed Upper Cambrian-Lower Ordovician Goodwin Limestone. The footwall of the fault beneath the fault zone is composed of the middle Cambrian Pole Canyon Limestone and Willow Springs member. Fault \#5 cuts, and is therefore younger than, fault \#6. Several granitic dikes cut fault \#5 on the south side of Heath Canyon, and one of these dikes is in turn cut by fault \#3 indicating that fault \#3 is younger than fault \#5.

Fault \#5 is a gently undulating surface that is broadly arched about a north-northwest trending axis (Fig. 13). The maximum dip of the fault is $19^{\circ}$ east (attitude derived trigonometrically from contouring the fault plane). Where the fault dips east, the Goodwin Limestone, which is stratigraphically above the network of fault slices at the base of the fault, dips an average of $\sim 25^{\circ}$ east (see cross section $D_{-}-D^{\prime}$ ). This suggests that strata in the hanging wall of fault \#5 dip more steeply east than the fault and therefore the fault cuts down section toward the west in its hanging wall. However, fault \#5 cuts down section to the east in its footwall in Heath Canyon (cross section D-D'). Consequently, the kinematics of this fault are not clear. It is possible, however, that fault \# 5 is top-to-the-west like the structurally overlying faults. This would require that the footwall rocks in Heath Canyon are broadly folded about a northerly trending axis with the rocks in the footwall having an overall westerly dip where exposed and then rolling over and dipping to the east in the subsurface to the east of the map area. A rollover in the footwall of fault \#5 is shown schematically in Figure 4 with the units in the hanging wall of fault \#5 being transported to the west. Such a broad roll-over of Cambrian strata in Heath Canyon would not be unusual because the Ordovician section in Beaty Canyon similarly rolls over from more steep east dips toward the east to much shallower east dips toward the west (e.g., see cross section B-B' on the map). 
Although the kinematics of fault \#5 are not well constrained, fault striae are present along the fault that juxtaposes the Little Meadows formation atop the Blue Eagle member in Blair Canyon (this fault forms part of the fault zone). The striae have an average plunge of $25^{\circ}$ in a southwest direction. However, this slip lineation may not be a reliable kinematic indicator of fault movement because it is nearly perpendicular to the north- to northwest-trending axis of the flexure in the fault surface (Fig. 13) and therefore could be related to flexural slip rather than faulting.

Fault \#5 appears to be largely a ductile fault. Sparse, poorly exposed phyllite with superposed foliations and marble tectonite that overprint the Mesozoic fabrics are present adjacent to the fault within the Pole Canyon Limestone. The Pole Canyon Limestone away from the fault does not exhibit such fabrics, suggesting that these fabrics are fault related. Brittle deformation, however, is present in the few places to the west where the tapered end of the hanging wall of fault \#5 is cut by younger low-angle normal faults. For example, in the southwest part of the map area northeast of Dry Basin, where fault \#5 is in proximity of faults \#3 and \#1 (see the west end cross-section E- $\mathrm{E}^{\prime}$ on the map) the rocks in the hanging wall of fault \#5 tend to be pervasively brecciated (Fig. 4B). In this area, the brecciation may be associated with slip along the overlying faults \# 1 and \#3.

Fault \#6. Fault \#6 is exposed near the mouth of Heath Canyon where it dips to the west and juxtaposes the Grant Canyon member atop the older Willow Springs member. The Willow Springs member beneath fault \#6 is a micaceous fine-grained marble that is pervasively folded and contains amphibole and phlogopite porphyroblasts. In contrast, the structurally overlying Grant Canyon member contains only a few mesoscopic folds and is composed of generally unrecrystallized fossiliferous argillaceous limestone and minor phyllite. Therefore fault \#6 juxtaposes less metamorphosed and deformed younger rocks over older rocks that appear more strongly metamorphosed and deformed. Fault \#6 is cut by faults \#5 and \#1. Because of the limited areal extent of fault \#6 in the map area, the geometry and kinematics of this structure are not constrained.

In various places, poorly exposed phyllite with superposed foliations is present adjacent to fault \#6 in the Grant Canyon member. The Grant Canyon member away from the fault does not exhibit such superposed foliations, suggesting that these fabrics are fault related and that fault \#6 is a ductile fault.

\section{Minor Map-Scale to Mesoscopic-Scale (Class 2) Normal Faults}

The minor normal faults constitute map-scale high-angle normal faults and high- to low-angle mesoscopic faults. The mapscale high-angle normal faults have dominantly north-northwest to north-northeast trends, dip to the east or west, and have minor displacements. Down-to-the-east faults predominate. Many of these faults cut, and therefore are demonstrably younger than, the low-angle normal faults. However, some high-angle normal faults occur entirely within the hanging wall of a low-angle nor- mal fault, or appear to sole into a low-angle normal fault. These faults can be older than, synchronous with, or younger than the major low-angle normal fault(s). The mesoscopic high- to lowangle normal faults overprint contractional fabrics and are typically present between the low-angle normal faults near where they intersect, i.e., at the tapered end of a fault slice (e.g., Fig. 4). Where displacement on these structures is discernible, based on offset layering, it is commonly down- or top-to-the-west. The age and relationship of the mesoscopic normal faults relative to the major low-angle normal faults is not constrained because crosscutting relationships were not found.

\section{Range-Front Fault System}

The youngest normal faults are marked by discontinuous fault scarps that cut pediment alluvium on the western margin of the map area. These faults define part of the west-dipping rangefront fault system (Fig. 14A), and locally they contain antithetic faults that define a graben (Fig. 3B). The footwall of this fault system contains an erosionally-embayed mountain front that is bordered by the pediment developed on Paleozoic bedrock (Fig. $3 \mathrm{~A})$ whereas the hanging wall contains Tertiary-Quaternary basin fill overlapping Paleozoic basement. In the Heath Canyon area, well data of Hulen et al. (1994) indicate that the basin fill is at least 5000 feet thick $\sim 5 \mathrm{~km}$ due west of the fault (Fig. 3C).

The age of the range-front faults can be broadly constrained to post-date Qf1 and predate Qal. All faults cut the oldest alluvial deposits Qf1, but locally in Heath Canyon, the faults cut Qf2, which is a younger alluvial surface incised into unit Qf1 (Fig. 3A). North of Heath Canyon Qf2 is not present in proximity of the faults and therefore the faults in this area can only be constrained to post date Qf1. All faults appear to predate the youngest alluvial deposits (Qal) because they are overlapped by unit Qal. The age of the faults relative to pluvial deposits is uncertain, however, the lake highstand may in places be superimposed on a degraded fault scarp (see map and Fig. 3A) suggesting that the lake high-stand and younger pluvial deposits post-date faulting.

\section{Extension, Magmatism, and Hydrothermal Alteration}

Extension was at least in part synchronous with magmatism as indicated by dikes in Heath Canyon that cross-cut various low-angle normal faults or are cut by a low-angle normal fault. Both granitic and andesitic dikes in Heath Canyon cut fault \#5, indicating emplacement post-dates slip along fault \#5. Granitic dikes, in turn, are cut by and therefore predate fault \#3. Hence, granitic magmatism accompanied low-angle normal faulting. Because there are no cross cutting relationships between the andesitic dikes and the younger low-angle normal faults (\#1- \#4) it is unknown whether andesitic magmatism post-dates or was in part synchronous with extension. Nonetheless, magmatism at depth may have driven hydrothermal alteration. Hydrothermal alteration is present in both the granitic dikes and Paleozoic rocks where it tends to be concentrated in rock adjacent to the 

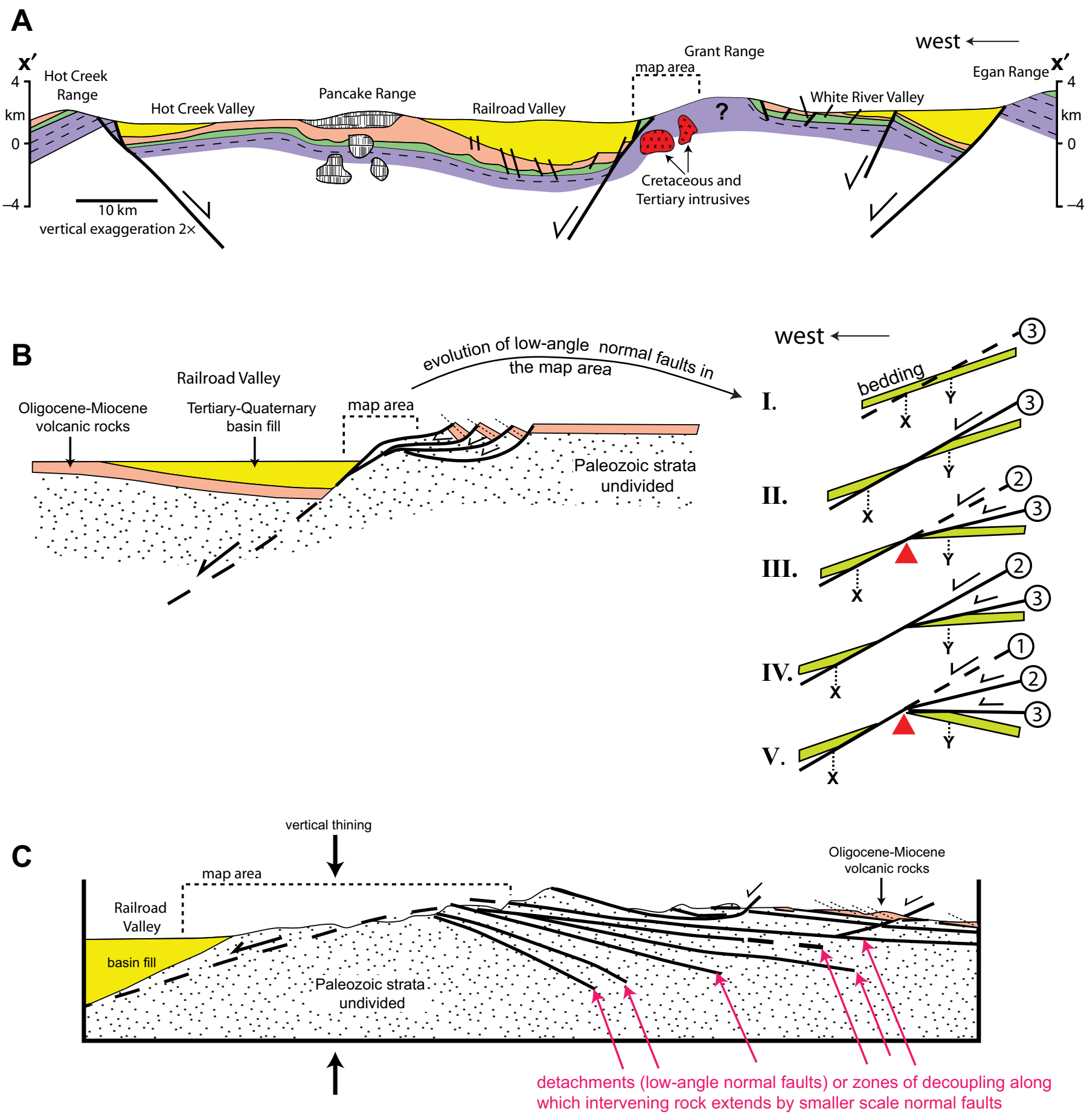

Figure 14. West-east cross sections through the Grant Range illustrating large scale structure and various interpretations of the origin of the low-angle normal faults. (A) Cross-section $\mathrm{X}-\mathrm{X}^{\prime}$ through the Grant and adjacent ranges. Only modern range bounding normal faults are shown; individual faults within the Grant Range are too small to show at this scale. Location of cross section is shown in Figure 1B; units are the same as in Figure 1B. (B) Schematic cross section on the left shows how the low-angle normal faults may be related to single, west-dipping normal fault with a break-away to the east. Diagram on the right shows the possible evolution of the low-angle normal system assuming they are all part of the same west dipping normal fault. "I" and "II" show the initial geometry of the fault and the Paleozoic section; both dip west but the fault dips more steeply than bedding. After slip along the fault in "II," the sketches in "III" and "IV" show that the part of the fault that is to the right of the red triangular pivot point rotates to the east and is rendered inactive and then the unrotated segment of the fault to the left of the pivot point propagates into the hanging wall. This process is repeated in "V" and results in a stack of low-angle normal faults in which each structurally higher fault is younger than the one below it. Diagrams are modified from Camilleri (1992). (C) Cross section showing Lund et al. (1993) interpretation of multiple stacked, structurally decoupled low-angle normal faults accommodating vertical uplift and exhumation. Modified after Lund et al. (1993). 
low-angle normal faults. Hence alteration appears to have taken place during the extensional phase of deformation. In addition to hydrothermal alteration, calcite- to quartz-filled extension veins are also present cross-cutting fault breccias and altered rock along the low-angle normal faults (Fig. 3A). The presence of these veins attests to high fluid pressures during and or following slip along the low-angle normal faults.

Areas of intense hydrothermal alteration range from 1 decimeter to several meters thick and tend to occur in zones adjacent to and paralleling the low-angle normal faults. The primary types of alteration are (1) dolomitization of limestone-commonly associated with tiny ( $2 \mathrm{~mm}$ thick) quartz veins, (2) silicification of limestone, and (3) orange to yellow iron oxide staining. In addition, metamorphic biotite or phlogopite tends to be altered to chlorite in proximity of low-angle faults. Silicified breccias are common along faults that cut thin-bedded limestone. The silicified breccias contain randomly oriented fragments of silicified limestone that are typically $2-5 \mathrm{~cm}$ long. The only place along any one particular fault where such a breccia occurs is where it is silicified, thus making a hydrothermal origin of brecciation more probable than a tectonic origin.

\section{CORRELATION, AGE, AND ORIGIN OF EXTENSIONAL STRUCTURES}

\section{Correlation and Age}

The age of low-angle normal faulting in the Grant Range is generally regarded as Tertiary (e.g., Moores et al. 1968, Fryxell, 1984, 1988; Lund et al. 1987, 1988; Camilleri, 1988, 1992; Horton and Schmitt, 1998). Although it is possible to more precisely constrain the age of some of the low-angle normal faults in the map area by dating the granitic dikes that cross-cut or are cut by them, at present they are undated. Nonetheless, age constraints can be inferred on the basis of comparison with kinematically and geometrically similar faults in adjacent areas in the Grant Range. In the map area, faults \#1, 2, 3, and 4 are geometrically constrained to be top-to-the-west whereas the sense of slip on faults \#5 and \#6 is unconstrained, although bedding-to-fault relationships in the hanging wall of fault \#5 are similar to that of faults \#1-4 suggesting that it is likely top-to-the-west as well. Other top-to-the-west low-angle normal faults are present in parts of the southern and northern Grant Range. In the northern Grant and southern White Pine ranges (Fig. 1B), top-to-the-west moderate to low-angle normal faults that contain east-dipping basin-fill strata in their hanging walls are Miocene or younger in age (e.g., Moores et al., 1968; Horton and Schmitt 1998). In the southern Grant Range, Fryxell (1984) recognized two generations of low-angle normal faults. The earlier generation is east-dipping, inferred to be top-to-the-east, and includes the Troy Peak fault (Fig. 1C) whereas the latter generation is west-dipping and top-to-the west. On the basis of cross-cutting relationships of the low-angle normal faults with dated volcanic rock, the topto-the-east faults are constrained to be post-late Oligocene and the top-to-the-west faults are Miocene or younger (Fryxell, 1984, 1988). There is no conclusive evidence of top-to-the east lowangle normal faulting in the map area and hence this early phase of extension recognized by Fryxell $(1984,1988)$ may not have affected the map area, however, the second phase is well represented by faults \#1-4 (and probably \#5). Hence the occurrence of Miocene or younger top-to-the-west low- to moderate-angle normal faults along the western flanks of the northern Grantsouthern White Pine and southern Grant Ranges would suggest that the family of top-to-the-west low-angle normal faults in the map area could also be Miocene or younger in age. The modern range-front faults that cut Quaternary deposits in the map area likely postdate slip along the low-angle normal faults. This inference is made because the footwall of the range-front fault system contains an extensive pediment that transitions into an erosionally embayed mountain front suggesting that the range-front fault scarps reflect renewed fault slip after a period of tectonic quiescence that produced the embayed mountain front (Camilleri et al., 2011). In summary, the low-angle normal faulting in the map area may be largely Miocene to Pliocene in age, predating slip along the modern range-front fault system.

\section{Origin of Extensional Structures and Exhumation of the Metamorphic Rocks}

Although the precise amount of extension accommodated by the array of low- to high-angle normal faults is poorly constrained, these faults accomplished at least $6 \mathrm{~km}$ exhumation, or vertical thinning, of the crust. This estimate is based on the stratigraphic depth of the Pole Canyon Limestone, which is the oldest and structurally deepest unit exposed in the map area (estimate is calculated from the thickness of equivalent, undeformed, unmetamorphosed Paleozoic stratigraphic units above and including the Pole Canyon Limestone mapped in the southern Egan Range by Kellogg [1963]). The amount of exhumation could be considerably more if the rocks were structurally buried by a thrust sheet(s), which is suggested by the presence of thrust faults that are dismembered by normal faults to the south of the map area (e.g., Fig. 1C). Nonetheless, exactly how the normal faults accomplished the exhumation of the metamorphic rocks is controversial. Two contrasting hypotheses about the origin, geometry, and kinematics of the normal faults have been proposed.

Camilleri $(1988,1992)$ proposed that the faults represent extinct, rotated segments of a major west-dipping normal fault that had a breakaway cutting Tertiary rocks on the east side of the Grant Range (Fig. 14B). This hypothesis was developed to explain the arched stack of low-angle normal faults with low bedding-to-fault angles in which each structurally higher fault is younger than the one below it. This model involves progressive eastward rotation of the upper part of an originally high- to low-angle west-dipping normal fault that initially cut a westdipping panel of Paleozoic strata (Fig. 14B, I-V). Such a westdipping panel could represent strata tilted on a thrust ramp (e.g., Fig. 12B) or the west-dipping limb of a north-trending anticline 
(e.g., Timber Mountain anticline). In the scenario proposed by Camilleri (1992), the fault dips more steeply than strata and progressive rotation of the upper part of the fault (Fig. 14B, I-V) is induced by isostatic rebound due to tectonic unloading as the hanging wall is translated to the east (e.g., similar to that proposed by Buck [1988]). The rotated part of the fault is rendered inactive and the unrotated segment of the fault propagates into the hanging wall. This process ultimately produces the observed geometry and relative ages of the low-angle normal faults. Camilleri (1992) interpreted the minor normal faults that cut lowangle normal faults and those that are present between the faults as bending moment faults formed in response to extension above a neutral surface at depth as the footwall bends and rotates.

In contrast to the scenario proposed by Camilleri (1988, 1992), Lund and Beard (1992), and Lund et al. (1993) proposed a model that involves bulk vertical thinning and heterogeneous lateral extension accommodated by multiple levels of detachments (low-angle normal faults) that developed subparallel to bedding in the Paleozoic section. They envision that the low-angle faults converge along the range-front into a single west-dipping fault (i.e., fault \#1), but diverge and die out to the east (Fig. 14C). In their interpretation the detachments were largely structurally decoupled from one another and the rocks between the detachments extended independently of each other with extension primarily accommodated by the smaller scale high- to moderate-angle normal faults. Lund et al. (1993) emphasize that extension was heterogeneous with the greatest amount of vertical thinning along the western flank of the range, resulting in uplift and arching of rocks and structures and ultimately relative uplift of the Grant Range and down-to-the-west dropping of Railroad Valley. Francis and Walker (2001) proposed a model similar to Lund et al. (1993) for the southern White Pine Range (Fig. 1B) as well as the Grant Range. Their model assumes a relatively flat lying Paleozoic section with no Mesozoic thrust faults or folds prior to extension and hence applicability to the southern Grant Range may be limited due to the presence of pervasive Mesozoic structure (for example as documented by: Hyde and Huttrer, 1970; Cebull, 1970; Fryxell, 1984, 1988, 1991; Lund et al., 1987, 1988; Camilleri, 1988; Bartley and Gleason, 1990; Taylor et al., 2000).

In summary, the models of Camilleri (1992) and Lund et al. (1993) are similar in that they both indicate that the arching of the low-angle normal faults was synchronous with extension but they differ fundamentally in two ways. First, in Camilleri's (1992) interpretation the low-angle normal faults are related to a single west-dipping normal fault that had a break away in Tertiary rocks to the east. In contrast, Lund et al. (1993) infer that the low-angle faults are largely structurally decoupled from one another and that west-dipping normal faults that cut Tertiary rocks in the eastern part of the range sole into a high level low-angle normal fault in Tertiary or upper Paleozoic strata and hence are unrelated to structurally lower low-angle normal faults. Secondly, Lund et al. (1993) appear to interpret the minor faults or faults between detachments to be primarily responsible for the bulk of extension and exhumation whereas Camilleri (1992) interprets these largely as bending moment faults superimposed during the latter stage of extension and hence are not primarily responsible for the bulk of extension.

\section{Relation of Low-Angle Normal Faults to the Range-Front Fault}

While it is clear that the low-angle normal faults are at least in part responsible for uplift and exhumation of rocks in the Grant Range, the relation of the youngest low-angle normal fault, fault \#1, to the modern range-front fault system is unclear. Fault \#1 projects into the west-dipping range front fault (Fig. 4), and on the basis of well and or seismic data from Railroad Valley, some workers postulate that the modern high-angle faults in the subsurface of Railroad valley cut the low-angle normal fault system (e.g., Anderson et al. 1983; Read and Zogg, 1988; Veal et al., 1988; Flannigan, 1988; Hulen et al., 1994; Fig. 3C) whereas others have suggested that the modern range-front fault system soles into and is related to the low-angle normal faults, in particular fault \#1 (e.g., Effimoff and Pinezich, 1981; Lund et al., 1993). Unfortunately, there is no consensus or conclusive evidence to indicate whether or not the range-front fault cuts or soles into the low-angle normal fault system. What appears more certain, however, is that the latest slip along modern range-front fault system occurred after a period of tectonic quiescence that produced the erosionally embayed mountain front and associated older alluvial deposits (Qf1) that overlap and post-date the low-angle normal fault system.

\section{DISCUSSION}

Much has yet to be resolved regarding the age, geometry, and evolution of contractional and extensional structures in the Grant Range. In particular, it is unclear what influence, if any, Mesozoic thrust faulting had on the evolution of the Cenozoic lowangle normal faults. The Grant Range was clearly the locus of Mesozoic thrust faulting as indicated by remnants of thrust faults dismembered by normal faults to the south of the map area (e.g., Cebull, 1970; Fryxell, 1991; Bartley and Gleason, 1990). Prior to extension, one or more of these thrust faults would likely have been present in the subsurface of the map area and hence probably controlled the pre-extensional geometry of the Paleozoic section. Camilleri (1992) suggested that the low-angle normal faults developed in a west-dipping Paleozoic section, possibly tilted on a west-dipping thrust ramp (e.g., Fig. 12B). This raises the possibility that a thrust fault could have been reactivated as a normal fault and or may have influenced the style of extension.

Structural relations in the map area provide an excellent opportunity for future work that could result in an important leap in the understanding of the (1) timing of thrust faulting and subsequent extension, and (2) the role that Mesozoic thrust faults played on the style, kinematics, and geometry of extensional features. For example, isotopic dating of dikes that crosscut and are cut by the low-angle normal faults could yield more precise age constraints on the timing of extension, which at present is only regionally 
constrained to be Tertiary in age. Isotopic dating of micas in cleavages may help constrain the ages of contractional deformation and metamorphism, which is tentatively only constrained to predate $86 \mathrm{Ma}$. In addition, a fuller understanding of the evolution of the low-angle normal faults and pre-extension structural geometry of rocks can be achieved by more detailed structural mapping of Silurian and younger Paleozoic rocks in the map area as well as detailed mapping and structural reconstruction of the area between Fryxell's $(1988,1991)$ study and the map area and of Paleozoic and Tertiary strata on the east flank of the range. Such detailed mapping is needed to assess the viability of the opposing models of extension proposed by Lund et al. (1993) and Camilleri (1992).

\section{ACKNOWLEDGMENTS}

I thank Michael Wells and Doug Walker for suggestions that helped to improve the map and manuscript. Thanks also to Jack Deibert and Sue Breeden for early discussions and assistance in mapping of Quaternary units and to Karen Lund, Sue Beard, and Joan Fryxell for introducing me to, and discussing, the complex structure and stratigraphy of the Paleozoic rocks. Geologic mapping of the Paleozoic bedrock was supported by grants from the Geological Society of America, American Association of Petroleum Geologists, Sigma Xi, Mobil Oil Corporation, Amoco Production Company, and Marathon Oil Company. Material and logistical support was provided by the U.S. Geological Survey and Chevron U.S.A.

\section{REFERENCES CITED}

Anderson, R.E., Zoback, M.L., and Thompson, G.A., 1983, Implications of selected subsurface data on the structural form and evolution of some basins in the northern Basin and Range province, Nevada and Utah: Geological Society of America Bulletin, v. 94, p. 1055-1072, doi:10.1130/0016 -7606(1983)94<1055:IOSSDO >2.0.CO;2.

Armstrong, R.L., 1982, Cordilleran metamorphic core complexes-from Arizona to southern Canada: Annual Review of Earth and Planetary Sciences, v. 10, p. 129-154, doi:10.1146/annurev.ea.10.050182.001021.

Bartley, J.M., and Gleason, G.C., 1990, Tertiary normal faults superimposed on Mesozoic thrusts, Quinn Canyon and Grant ranges, Nye County, Nevada, in Wernicke, B.P., ed., Basin and Range extensional tectonics near the latitude of Las Vegas, Nevada: Geological Society of America Memoir 176, p. $195-212$.

Buck, W.R., 1988, Flexural rotation of normal faults: Tectonics, v. 7, p. 959973, doi:10.1029/TC007i005p00959.

Camilleri, P.A., 1988, Superposed compressional and extensional strain in metamorphosed lower Paleozoic rocks of the northern Grant Range, eastcentral Nevada [M.S. thesis]: Corvallis, Oregon, Oregon State University, $84 \mathrm{p}$.

Camilleri, P.A., 1992, Extensional geometry of a part of the northwestern flank of the northern Grant Range, Nevada: inferences on its evolution: The Mountain Geologist, v. 29, p. 75-84.

Camilleri, P.A., Deibert, J.E., and Breeden, S., 2011, Preliminary geologic mapping and Quaternary faulting of the western margin of the Grant Range, east-central Nevada: Geological Society of America Abstracts with Programs, v. 43 , no. 5 , p. 277.

Cebull, S.E., 1967, Bedrock geology of the southern Grant Range, Nye County, Nevada [Ph.D. thesis]: Seattle, Washington, University of Washington, $130 \mathrm{p}$.

Cebull, S.E., 1970, Bedrock geology and orogenic succession in the northern Grant Range, Nye County, Nevada: The American Association of Petroleum Geologists Bulletin, v. 54, p. 1828-1842.
Cook, H.E., and Taylor, M.E., 1977, Comparison of continental slope and shelf environments in the upper Cambrian and lowest Ordovician of Nevada, in Cook, H.E., and Enos, P., eds., Deep-water carbonate environments: Society of Economic Mineralogists and Paleontologists Special Publication No. 25, p. 51-82.

Coney, P., 1980, Cordilleran metamorphic core complexes: an overview, in Crittenden, M.D., Coney, P.J., and Davis, G.H., eds., Cordilleran Metamorphic Core Complexes: Geological Society of America Memoir 153, p. 7-34.

Coney, P., and Harms, T., 1984, Cordilleran metamorphic core complexes: Cenozoic extensional relics of Mesozoic compression: Geology, v. 12, p. 550-554, doi:10.1130/0091-7613(1984)12<550:CMCCCE >2.0.CO;2.

Crittenden, M., 1980, Metamorphic core complexes of the North American Cordillera: summary, in Crittenden, M.D., Coney, P.J., and Davis, G.H., eds., Cordilleran Metamorphic Core Complexes: Geological Society of America Memoir 153, p. 485-490.

Drewes, H., and Palmer, A.R., 1957, Cambrian rocks of the southern Snake Range, Nevada: The American Association of Petroleum Geologists Bulletin, v. 41, p. 104-120.

Effimoff, I., and Pinezich, A.R., 1981, Tertiary structural development of selected valleys based on seismic data: Basin and Range Province, northeastern Nevada: Philosophical Transactions of the Royal Society of London, v. A300, p. 435-442.

Flannigan, D.M.H., 1988, Kate Spring Field discovery: Nevada Basin and Range: The Mountain Geologist, v. 25, p. 159-170.

Francis, R.D., and Walker, C.T., 2001, The Role of Attenuation in the Formation of the Railroad Valley Structural Basin, East-Central Nevada: Detachment Control of Petroleum Reservoirs: The American Association of Petroleum Geologists Bulletin, v. 85, p. 1153-1182.

Fryxell, J.E., 1984, Structural development of the west-central Grant Range, Nye County, Nevada [Ph.D. thesis]: Chapel Hill, University of North Carolina, $139 \mathrm{p}$.

Fryxell, J.E., 1988, Geologic map and descriptions of stratigraphy and structure of the west-central Grant Range, Nye County, Nevada: Geological Society of America Map and Chart Series MCHO64.

Fryxell, J.E., 1991, Tertiary tectonic denudation of an igneous and metamorphic complex, west-central Grant Range, Nye County, Nevada: Geology and Ore Deposits of the Great Basin Symposium sponsored by the Geological Society of Nevada, p. 87-92.

Hamilton, W. B., 1988, Detachment faulting in the Death Valley region, California and Nevada. U.S. Geological Survey Bulletin 1790, p. 51-85.

Horton, B.K., and Schmitt, J.G., 1998, Development and exhumation of a Neogene sedimentary basin during extension, Nevada: Geological Society of America Bulletin, v. 110, p. 163-172, doi:10.1130/0016-7606 (1998) $110<0163:$ DAEOAN $>2.3 . C O ; 2$.

Hulen, J.B., Goff, F., Ross, J.R., Bortz, L.C., and Bereskin, S.R., 1994, Geology and geothermal origin of Grant Canyon and Bacon Flat oil fields, Railroad Valley, Nevada: The American Association of Petroleum Geologists Bulletin, v. 78, p. 596-623.

Humphrey, F. L., 1960, Geology of the White Pine mining district, White Pine County, Nevada: Nevada Bureau of Mines and Geology Bulletin 57.

Hyde, J.H., and Huttrer, G.W., 1970, Geology of the central Grant Range, Nevada: The American Association of Petroleum Geologists Bulletin, v. 54 , p. $503-521$.

Kellogg, H.E., 1963, Paleozoic stratigraphy of the southern Egan Range, Nevada: Geological Society of America Bulletin, v. 74, p. 685-708, doi:10.1130/0016-7606(1963)74[685:PSOTSE]2.0.CO;2.

Kleinhampl, F.J., and Ziony, J.I., 1985, Geology of northern Nye County, Nevada: Nevada Bureau of Mines and Geology, Bulletin 99A, $172 \mathrm{p}$.

Lund, K., Nash, J.T., Beard, L.S., Blank, H.R., Jr., and Tuftin, S.E., 1987, Mineral resources of the Blue Eagle Wilderness Study Area: U.S. Geological Survey Bulletin 1731-D.

Lund, K., Beard, L.S., Blank, H.R., Jr., and Hofstra, A.H., 1988, Mineral resources of the Riordans Well Wilderness Study Area, Nye County, Nevada: U.S. Geological Survey Bulletin 1731-H.

Lund, K., and Beard, L.S., 1992, Extensional geometry in the northern Grant Range, east-central Nevada-implications for oil deposits in Railroad Valley: U.S. Geological Survey Bulletin 2012, p. I1-I9.

Lund, K., Beard, L.S., and Perry, W.J., 1993, Relation between extensional geometry of the northern Grant Range and oil occurrences in Railroad Valley, east-central Nevada: The American Association of Petroleum Geologists Bulletin, v. 77, p. 945-962. 
Moores, E.M., Scott, R.B., and Lumsden, W.W., 1968, Tertiary tectonics of the White Pine-Grant Range region, east-central Nevada, and some regional implications: Geological Society of America Bulletin, v. 79, p. 1703 1726, doi:10.1130/0016-7606(1968)79[1703:TTOTWP]2.0.CO;2.

Nelson, R.B., and Lindsley-Griffin, N., 1987, Biopressured carbonate turbidite sediments: A mechanism for submarine slumping: Geology, v. 15, p. 817-820, doi:10.1130/0091-7613(1987)15<817:BCTSAM>2.0.CO;2.

Nolan, T.B., Merriam, C.W., and Williams, J.S., 1956, The stratigraphic section in the vicinity of Eureka, Nevada: U.S. Geological Survey Professional Paper 276, p. 1-77.

Read, D.L., and Zogg, W.D., 1988, Description and origin of the Devonian dolomite oil reservoirs, Grant Canyon field, Nye County, Nevada, in Goolsby, S.M., and Longman, M.W., eds., Occurrence and petrophysical properties of carbonate reservoirs in the Rocky Mountain region: Rocky Mountain Association of Geologists Guidebook, p. 229-240.

Reheis, M.C., 1999, Extent of Pleistocene lakes in the western Great Basin: U.S. Geological Survey Miscellaneous Field Studies Map MF-2323, scale $1: 800,000$.
Serra, S., 1977, Styles of deformation in the ramp regions of overthrust faults, in Heisey E.L., Lawson D.E., Norwood, E.R., Wach, P.H., and Hale, L.A., eds., Rocky Mountain thrust belt geology and resources: Wyoming Geological Association 29th Annual Field Conference, p. 487-498.

Stewart, J.H., and Carlson, J.E., 1977, Geologic map of Nevada: Nevada Bureau of Mines and Geology, Map 57, Scale 1:1,000,000.

Taylor, W.J., Bartley, J.M., Martin, M.W., Geissman, J.W., Walker, J.D., Armstrong, P.A., and Fryxell, J.E., 2000, Relations between hinterland and foreland shortening, Sevier orogeny, central North American Cordillera: Tectonics, v. 19, p. 1124-1143, doi:10.1029/1999TC001141.

Veal, H.K., Duey, H.D., Bortz, L.C., and Foster, N.H., 1988, Grant Canyon and Bacon Flat oil fields, Railroad Valley, Nevada: The Mountain Geologist, v. 25 , p. $193-209$.

Wernicke, B., and Axen, G.J., 1988, On the role of isostasy in the evolution of normal fault systems: Geology, v. 16, p. 848-851, doi:10.1130/0091 -7613(1988)016<0848:OTROII >2.3.CO;2.

Manuscript AcCePted by the Society 5 February 2013 